\title{
STEALTHING AS A FORM OF RAPE - FINDINGS TO DATE AND FUTURE PROSPECTS FOR RESEARCH
}

\author{
Maciej BOCHEŃSKI, Mateusz ŻEBRACKI \\ Jagiellonian University, Kraków, Poland
}

\begin{abstract}
Stealthing or non-consensual condom removal (a situation in which one sexual partner, not necessarily a man, removes or damages a condom during intercourse and the other partner remains unaware of this fact) is a new phenomenon that has only recently been addressed by researchers. This article offers a summary of findings regarding the motives and methods of perpetrators' of stealthing and attempts to analyse this phenomenon from the perspective of Polish criminal law. Finally, it discusses the prevalence of the offences of rape and its subtypes and outlines the key issues involved in the quantitative analysis of rape.
\end{abstract}

\section{Keywords}

Sexual offences; Rape; Stealthing; HIV.

Received 5 July 2021; accepted 17 August 2021

In the third decade of the twenty-first century - now underway - criminology and the doctrine of criminal law is focussed on the identification and description of new human behaviours as acts subject to evaluation in criminal law, which in the main is achieved through the application of new techniques of mass, remote communication and of data transmission (Mamak, 2017). Sexual offences are no exception. Recent years have seen the introduction of sanctions for the types of sexual offences defined in Article 191a, Article 202a, and Article 202b of the Polish Criminal Code, which indicate that the tendencies of the legislature's interest in this particular area of regulation have often been ill-advised (Warylewski, 2015). Meanwhile, what might be described as classical sexual crime remains almost unaltered since the dawn of contemporary Polish criminal law - as the most obvious example, Article 197 of the Criminal Code, demonstrates (Budyn-Kulik, 2013). In a world of such rapid change, in which awareness of reproductive rights and, more broadly, of the realm of sexual autonomy, is progressively shifting, it is impossible, however, to ignore or trivialise certain aspects of human action that have so far eluded, as it were, regulation and classification.

The phenomenon of stealthing or non-consensual condom removal (Latimer et al., 2018), which is the practice whereby a condom is removed or damaged by one partner (it does not have to be a man) without the knowledge of the other during intercourse, is very definitely one of them. The motivating factors that lead to such behaviour are varied, but the following, preliminary classification serves our present purposes:

- Dominating a partner and exercising power over them (deciding on the form of sexual activity);

- Risky sexual behaviour (the possibility of unwanted pregnancy or of an STD: sexually transmitted disease);

- Revenge (in most case perpetrated by carriers of STDs);

- The right to unconstrained reproduction (essentially in heterosexual relationships, in which men manifest their right to natural fatherhood and the transmission of their genes in this way); 
- Pragmatism (the argument that using a condom impairs the pleasure derived from sexual intercourse);

- The psychological aspect: the desire, for example, not to lose a partner and to engage in stealthing in the hope that it will result in pregnancy.

Despite the rather wide disparity between the elements influencing the motivations of perpetrators, the conduct itself is essentially a matter of two actions that produce similar results: removing or damaging a condom. To proceed with our considerations, it is necessary to distinguish a situation in which the partners agree to have sexual intercourse without a condom from one in which the agreement to do so is no more than apparent. As for condom damage, this often begins not under conditions of sexual arousal, during or shortly before sexual activity, but well in advance, as demonstrated by various instructional videos distributed on the Internet showing how to cut or perforate a condom in an unnoticeable way so that it cannot prevent conception or STDs (McCauley, 2016). Situations in which, in the hope of becoming pregnant and having a child, women tell men before intercourse that, contrary to the truth, they are using hormonal contraception, should be excluded here. This phenomenon, it would appear, involves utterly different motivational grounds and for this reason remains beyond the scope of stealthing and, therefore, of this paper. Indeed, it should not be forgotten that the very definition of stealthing reduces this behaviour to the unobserved removal of a condom. It is obvious that the misunderstandings, deceits, or lies that occur between sexual partners in relation to the method of contraception to be used are not restricted exclusively to the covert removal of condoms. Nevertheless, it is assumed in the literature that the concept of stealthing is to be understood only as this form of action: the form of action described in the introduction to this paper (McCauley, 2016; Latimer et al., 2018).

To gain a closer understanding of the phenomenon in question, it would appear important and necessary to develop and conduct a wider analysis of the impulses and motivating factors that guide perpetrators. What is at issue where the ultima ratio principle of criminal law is concerned (Gardocki, 2016) is not so much that punishment should be a last resort in itself, but that the necessity to punish appears as an expression of defeat incurred by the state apparatus (and, by implication, by society in relation to the perpetrator) and as an expression of powerlessness in the realms of prevention and probation. It is clear too that the 'opponent', which is human nature with its particular propensity for dangerous, risky, and novel behaviour, is an extremely difficult one (Kwiatkowska, Siudem, 2012;
Grabowska, 1995). Yet as always when the criminal law is applied, a scrupulous assessment must be made of where mutually approved risky behaviour ends and the abuse and ill-treatment of another person begins.

That the need for power and domination is satisfied in sexual relationships between people does not appear to be in doubt (Mandal, Kocur, 2015; Knight, Prentky, 1990; Dominiak, 2007). And at least in the West, approbation of a negative valuation of violence in sexual relations - unless, of course, consent is given - is equally widespread (Graupner, 2000). Certain objections are raised, however, regarding the moment and form of expressions of consent and regarding the content of the notion of consent, which remain a matter of debate (Płatek, 2018; Schulhofer, 1995, 1998; MacKinnon, 1991, 2006). In the West now, a sexual partner is subject to criminal liability where they do not respect the will of the other person regarding their sexual autonomy (Graupner, 2000). Clearly, the rules that have been elaborated excite objections in respect of individuals' presumed right to decide the extent of what is permitted and what is not. The body of work in the humanities and social sciences that studies sex as a socio-cultural phenomenon as distinct from sex as a biological phenomenon can be consulted for a more detailed discussion of this issue (Lorber, 2010). Feminist criminology, as one example of this school of thought, argues that particular beliefs, myths, and stereotypes function socially that place the power to decide the scope and form, and even the very occurrence of sexual intercourse, in the hands of one, privileged party: the man (Płatek, 2018; Schulhofer, 1995, 1998; MacKinnon, 1991, 2006). In actual instances of stealthing, perpetrators mislead partners by pretending to want to have sexual intercourse using a condom. Then, while the act is in progress, often through a sexual impulse that activates a desire for power and domination, they remove the protection. Often when this pattern is followed, the person removing the condom informs their partner that they are doing so. In the former's opinion this is a matter of no consequence: it is not to be discussed and does not constitute an important aspect of the latter's autonomy of will.

Borderline behaviours, or risky behaviours in general, arouse a sexual tension that can, to a greater or lesser extent, lead many people to engage in, or not to engage in, particular sexual activities (Grabowska, 2014). Two basic subtypes can be identified among these behaviours: the risk of falling pregnant and the risk of contracting, or the desire to contract, an STD (Imacka, Bulsa, 2012). No particularly frequent occurrence of the phenomenon of women being interested in unplanned pregnancy can be detected in the existing 
body of research (Kusio, 2004; Koronkiewicz, 2014). Where there is abuse or deception on the part of women, it is most often a matter of contriving fertilisation. Here their partners do not so much remove condoms wihtout the knowledge or consent of the women as have sexual intercourse without one when labouring under the misapprehension that the women are using hormonal contraception.

The second subtype, however, was identified and described among men who have sex with men (MSM; Klein, 2014). Its beginnings can be traced to the second half of the 1980s when, following the trauma of the HIV epidemic, effective retrovirus therapies and widespread prevention in the form of condoms were introduced, and the idea of safe sex became broadly accepted. Yet a group that perceived risky sex as attractive emerged to contest these responses (Klein, 2014). It was also then that attention was first drawn to the practice of using deception and coercion to have risky sex with 'safe bottoms' (men who wish to have intercourse wearing a condom). In the twenty-first century, retroviral therapy developed rapidly and became considerably simpler (nowadays a small amount of the drug is taken daily, usually in a single dose), social taboos around HIV and AIDS were broken, and pre-exposure prophylaxis medication (PrEP), which prevents HIV infection and a number of other viral STDs, became available. At the other end of the continuum in question, however, increasingly radical attitudes have appeared among a community of people who derive their greatest pleasure precisely from risky sexual behaviour, including from the opportunity to contract an STD or HIV. One of the phenomena present in this community is generationing, which involves ill men knowingly infecting healthy ones, following which they collaborate to infect another man. A similar occurrence is gift-giving, whereby HIV-negative men actively seeking to be infected are referred to as bug-chasers, and HIV-positive men who want to infect someone are known as gift-givers or 'poz', which is a shortened version of the word 'positive' in 'positive HIV test' (Klein, 2014). There should be no doubt that the spread of such practices and behaviours generates a significant public health risk, as it can undermine years of effort invested by sex educators in HIV prevention (Izdebski, 2003; Szeląg, Wąż, 2015).

Unfortunately, the nature of the phenomenon, which can be described as 'HIV mania', makes it difficult to determine its extent. Quantitative and qualitative studies alike encounter the same obstacle: insufficient numbers of potential respondents (sought on Internet forums or social networking services) willing to provide answers. Nevertheless, examination of the contents of some social networking services confirms that it is by no means a marginal phenomenon or one that can be neglected. The following series of posts from the social networking service Twitter should serve to familiarise readers with the attitudes displayed by 'HIV maniacs'.

Taking revenge on future, unknowing sexual partners for past events that led to someone's own infection is also regarded as a potential motive for stealthing (Cynkier, 2018). This particular motive is considered more broadly from the point of view of criminal responsibility under Article 161 of the Criminal Code, as this type of prohibited act was introduced to that statute in the face of media reports and public discourse about situations in which a man deliberately infected anywhere between fifteen and one-hundred women with the HIV virus and there was no legal instrument

Figures 1-6. Examples of entries placed on the Twitter social networking site by people practicing stealthing.

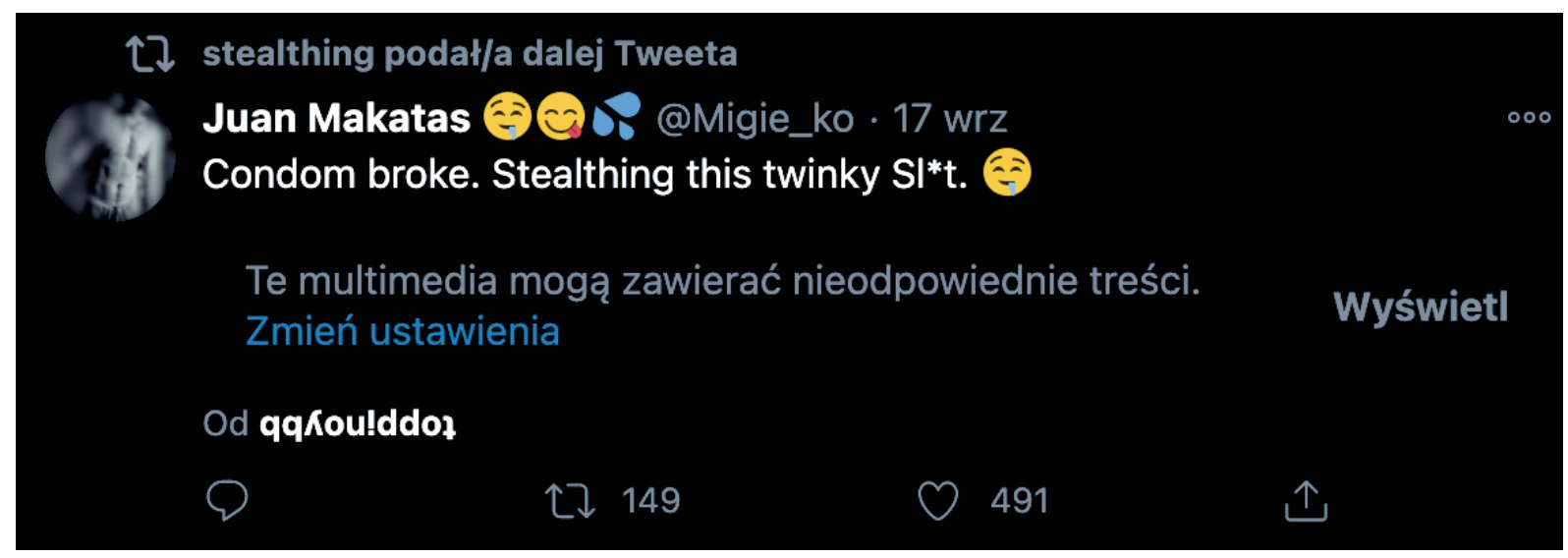

Fig. 1. "Condom broke. Stealthing this twinky S1*t." 


\section{†. Poz Pigs :-3 podał/a dalej Tweeta}

Toxic Seed is Life @ToxicSeed4Life · 9 gru

Loaded up a neg 18 yo sub boy tonight. Merry Christmas $:$. 어

Te multimedia mogą zawierać nieodpowiednie treści.

Zmień ustawienia

Wyświetl
Q 5
七】 9
○ 112
个.
Pokaż ten wątek

Fig. 2. "Loaded up a neg 18 yo sub boy tonight. Merry Christmas."

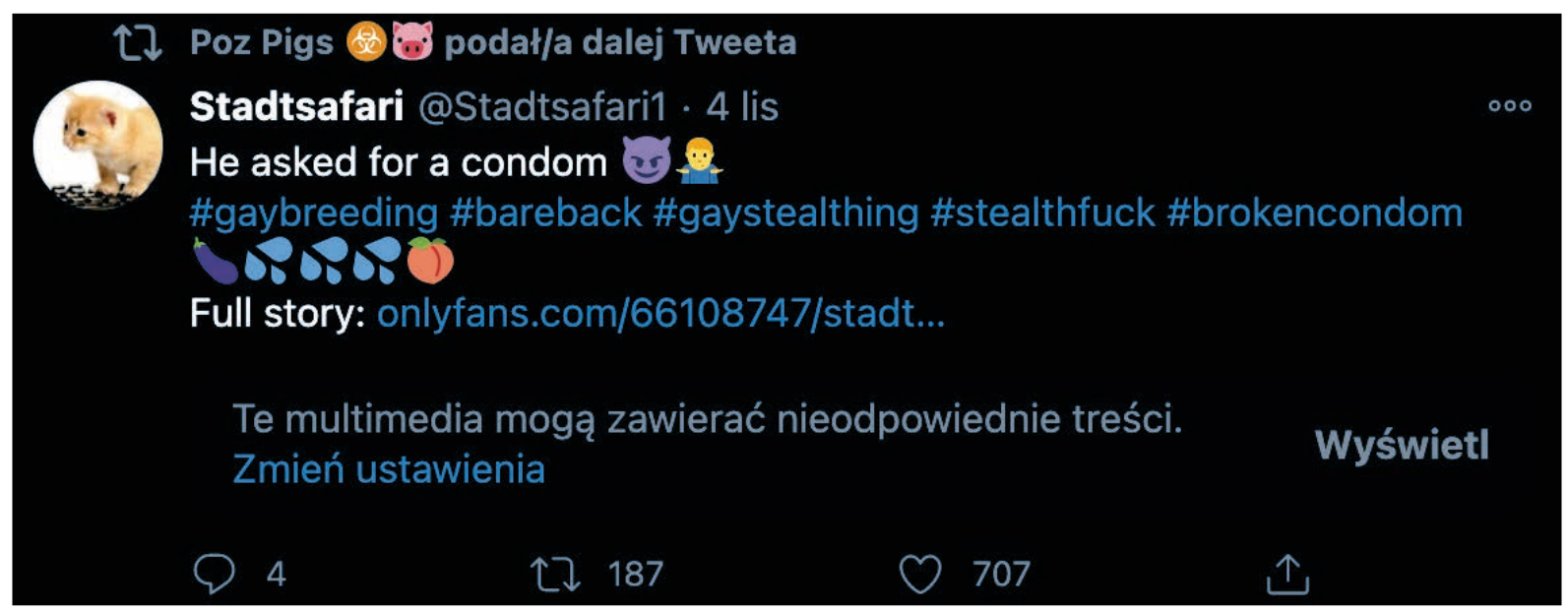

Fig. 3. "He asked for a condom."

Poz Breeder @poz_breeder · 29 lis

Confirmation of my toxic cock bringing another faggot into the brotherhood. \#bbbh \#pozzing \#poz4neg

Te multimedia mogą zawierać nieodpowiednie treści. Zmień ustawienia

Wyświetl

๑ 17 亿 31

O 219

Fig. 4. "Confirmation of my toxic cock bringing another faggot into the brotherhood." 


\title{
Poz Breeder
}

@poz_breeder

\section{If he has you wear a condom then stealth him...}

\section{twitter.com/Emperradorr1/s...}

\author{
Ten Tweet jest niedostępny.
}

\section{5:03 AM - 5 wrz 2020 - Twitter for iPhone}

Fig. 5. "If he has you wear a condom then stealth him..."

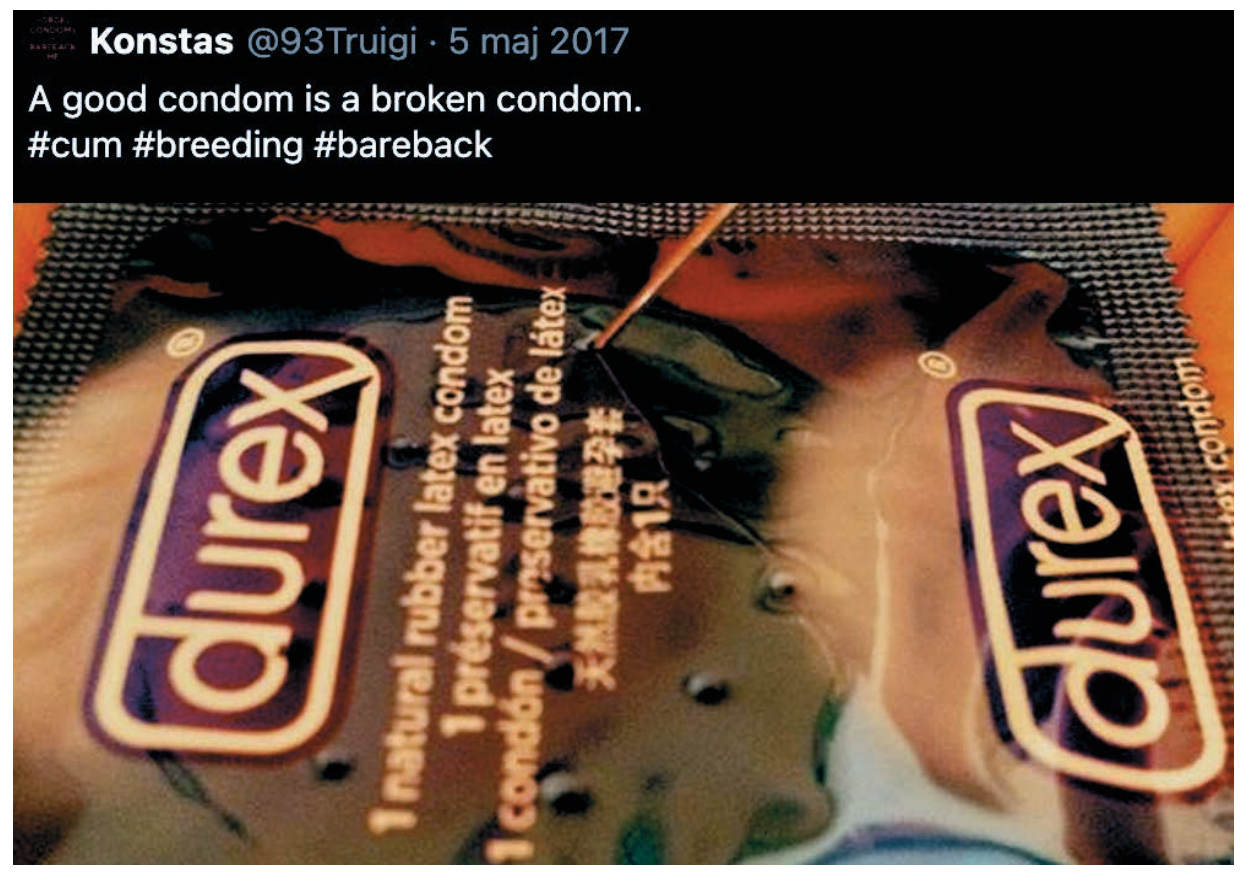

Fig. 6. "A good condom is a broken condom."

available that could properly classify such behaviour in terms of criminal law (Burek, Gajewska, 2008; Brodzikowska, Karge, Pałka, 2018; Mielnik, 1997; Jakubowicz, Jakubowicz, Żaba, Czarnecka-Operacz, 2009). Consideration of the revenge mechanism in itself reveals it as a process of mitigation whereby an infected person, who is angry and frustrated, seeks to pass their 'evil' once more along the chain and in this way - because they experienced the same thing themselves - to derive the satisfaction that they are not alone in suffering the negative effects of illness, in being naive enough, in being unintelligent enough, or in being unlucky enough to have become infected during the course of sexual activity.

Turning to a further potential motive, and to further potential causes, for the behaviours under discussion here, it is worth setting out the significance of certain changes to gender roles. Changes in gender roles and in social attitudes to the classical models of motherhood and fatherhood have brought about a situation in which the will and opinion of women regarding when and how many children to have is binding on men too (Dąbrowska, 2010). Second- and third-wave feminism has also altered perceptions of whether it 
is necessary at all for women to find partners to start families with (Grygiel, 2010). This has caused, to put it in somewhat colourful terms, a deficit of women and greater rivalry between men over female sexual partners (Głażewska, 2010). The formation of the response to feminism known as the involuntary celibate (Incel) online subculture, which is made up of men who straightforwardly declare their hatred of women, has activated attitudes associated with the perception that the liberation of women from the patriarchal system denies men the opportunity to become fathers and pass on their genes (Radomski, 2010; Zdrojewicz, Lelakowska, 2006). However, being aware of prevailing social relations and, for the most part, not manifesting their views in the public sphere other than through anonymous posts on blogs and on Internet fora, they engage in one-off, casual sexual encounters during which, without risking exposure to the financial and social costs of fatherhood, they pass on their genes to their unwitting partners, as if 'punishing' them for the social change brought about by feminism and emancipation (Arcimowicz, 2010; Ecler-Nocoń, 2016).

The pragmatic argument is most prevalent in conventional, stable heterosexual and homosexual relationships: using a condom significantly reduces the satisfaction derived from intercourse because a condom feels unpleasant to the skin of the penis, the man in question is allergic to latex, the condom is the wrong size, it pinches, it makes an erection or full ejaculation impossible, and it produces unpleasant smells and tastes (Hryneńko, 2011; Jabłońska, Naworska, Duda, Nieckula, Drosdzol-Cop, 2019). If the other partner approves of this approach to condom use, there is of course no question of stealthing being involved. But if one partner removes a condom without the other's knowledge and consent, it is an instance of stealthing.

At least at first glance, analysis and evaluation of the phenomenon of stealthing, which is described in the first section of this paper, is on the whole relatively straightforward from the point of view of criminal law. Where we are faced by conduct during sexual activity that involves one person acting in a way the other disapproves of (removal of a condom), the crime of rape cannot be disregarded as an appropriate legal classification. For the sake of thorough argumentation, it is advisable to begin by offering at least an outline juridical analysis of the offence of rape as it is set out in the criminal code currently in force in Poland. The offence of rape is the type of prohibited act defined in Article 197 of the Criminal Code, which reads as follows:

"Article 197, Paragraph 1. Whoever by force, unlawful threat, or deceit induces another person to have sexual intercouse shall be subject to the penalty of imprisonment for a term of between two years and twelve years.

Paragraph 2. If the perpetrator, in the manner specified in Paragraph 1, induces another person to submit to another sexual act or to perform such an act, he/ she shall be subject to the penalty of imprisonment for a term of between six months and eight years.

Paragraph 3. If the perpetrator commits rape:

1) Jointly with another person,

2) On a minor under fifteen years of age,

3) On an ascendant, descendant, adoptee, adopter, brother or sister, he/she shall be subject to the penalty of imprisonment for a term not shorter than three years. Paragraph 4. If the perpetrator of an act specified in Paragraphs 1-3 acts with particular cruelty, he/she shall be subject to the penalty of imprisonment for a term not shorter than five years."

As a thorough analysis of the type of prohibited act defined in Article 197 of the Criminal Code lies beyond the scope of the present text, it is advisable to focus primarily on the doctrinal issues that are relevant to stealthing.

As indicated in the subject literature, the good that is protected in Article 197 of the Criminal Code is sexual autonomy understood as freedom 'from' any and all duress regarding the taking of decisions in respect of sexual relationships, and hence freedom from coercion in the realm of sexual behaviour (Rodzynkiewicz, 2006; Andrejew, 1986). In accordance with the established position of the Supreme Court of the Republic of Poland, the protection of sexual autonomy in Article 197 of the Criminal Code entails the right to decide the place, time, manner, and other conditions and circumstances of sexual activity (Supreme Court Ruling, 2001). When sexual autonomy is understood in this way, rape is a glaring manifestation of its violation. If the means of force, threat, and deceit set out in Article 197 of the Criminal Code are used against a victim, how can there ever be any question of them exercising their free will, or taking a free decision, in respect of their sex life? If it occurs at all, it must be exceedingly rare (Bielski, 2006; Filar, 1985). It should be noted that the case law of the Supreme Court has consistently emphasised that the purpose of the perpetrator's action is irrelevant under the body of criminal law now in force. What is relevant, though, is whether their behaviour - corresponding to the statutory description - constitutes a violation of the victim's sexual autonomy (Supreme Court Ruling, 2001; Supreme Court Judgment, 2007). It is worth noting in this context that criminal liability under Article 197 of the Criminal Code is excluded where a perpetrator does not threaten the legal good that is sexual autonomy 
- even if their behaviour, for example mouth-to-mouth resuscitation or performing an enema, interferes with the bodily integrity of another person's intimate areas (Bielski, 2006).

Also pertinent here is the Supreme Court Judgment of 26 October 2001, which stated that the removal of pubic hair as a coarse practical joke did not constitute a prohibited act under Article 197 Paragraph 3 in conjunction with Article 197 Paragraph 2 - of the Criminal Code. Although the perpetrators touched the victim's genitals, this was not behaviour intended to violate sexual autonomy, but at the most constituted the lesser offence of an infringement of the victim's physical integrity (Supreme Court Judgment, 2001). It is therefore worth underlining that, in the current interpretation of the type of prohibited act described in Article 197 of the Criminal Code, the criminal liability of a perpetrator of rape rests on the violation of the sexual autonomy of a victim, and not on a perpetrator's psychological attitude towards the act as this is manifested when they seek to satisfy their sexual drive. The criminal violation of sexual autonomy may therefore occur for non-sexual reasons (Bielski, 2006).

As far as the statutory features of the crime of rape are concerned, it should be pointed out that the doctrine of criminal law distinguishes the absence of the victim's consent as a statutory feature of this type of prohibited act. To state that consenting to sexual intercourse $^{1}$, or to another sexual act, excludes the criminal unlawfulness of the behaviour described in Article 197 of the Criminal Code, is as important as it is obvious (Warylewski, 2004; Górniok, 2005; Bielski, 2006). It is worth stressing that absence of consent must exist at the moment of the act (Supreme Court Judgment, $1980,1979)$ and that, in principle, it should be verbalised in some manner - or at least given outward expression (Warylewski, 2004). Force, unlawful threat, and deceit are also statutory features of the crime defined in Article 197 of the Criminal Code. In considering deceit as a statutory feature of the crime of rape, it is worth beginning with the position taken by the Supreme Court based on the previous Criminal Code: that within the meaning of the provisions governing rape, deceit is taken in essence to denote artifices deployed by a perpetrator that would be capable of inducing even a prudent woman to submit to a lascivious act (Supreme Court Judgment, 1974). The Supreme Court drew explicit attention in the above judgment to the

\footnotetext{
1 Translator's note: The Polish term obcowanie ptciowe is rendered here as sexual intercourse, which should be taken to refer to vaginal, anal, and oral sex - both homosexual and heterosexual - as well as to other activities, including those that do not involve the genitals.
}

individual-objective criterion when assessing whether the perpetrator's conduct satisfied the statutory test for the use of deception. The Supreme Court expressed itself similarly in its judgment of 27 May 1985, in which it stated that, "The deceit referred to in Article 168 can consist in fabricating appearances in such a way that a victim consents to a lascivious act that they would not have consented to had they not been misled, or in strategems that induce a state in the victim, such that they are not fully cognizant of their actions or are unable to offer resistance. That said, deceit within the meaning of Article 168 excludes, or considerably limits, the will of a victim to resist being led intentionally in this way by a perpetrator to submit to a lascivious act" (Supreme Court Judgment, 1985).

Two approaches to the understanding of deceit in the context of the crime of rape have gained recognition in the doctrine and case law: in what is known as the narrow approach, it consists both in eliciting and exploiting a mistake made by a victim in connection with the motivational grounds for a decision to engage sexually, while in the broad approach it involves (preceded by misleading a victim or taking advantage of a mistake made by a victim) inducing a state in a victim that - by disabling their decision-making capacity or motor functions - precludes free sexual self-determination (Filar, 1974). The subject literature informs us that behaviour is also deceitful and cannot be acknowledged as legally relevant consent to sexual activity where it leads to a victim taking an independent decision in respect of making sexual contact but the victim is acting under a misapprehension (Bielski, 2006; Filar, 1974). A relevant error in terms of correspondence with the statutory definition of deceit in Article 197 of the Criminal Code occurs where an individual vested with the legal good of sexual autonomy decides to consent to sexual intercourse without knowing the full facts relevant to taking that decision. This may be illustrated by the following examples: (1) cases of mistaken identity (the victim's sexual partner is someone other than the person they believe them to be) and (2) cases in which perpetrators who are not doctors mislead victims by stating that the touching of intimate areas is a component of a medical examination (Bielski, 2006). In the context of the phenomenon this paper addresses there should be no doubt that stealthing - the removal of a condom without the knowledge and consent of a sexual partner - corresponds with the statutory features of the crime of rape committed by deception. Where a person agrees to engage in sexual intercourse with another person with the proviso that a condom is to be used, its removal without the knowledge and consent of the person who 
made this stipulation constitutes an unquestionable case of inducement to sexual intercourse by deception under conditions to which the victim did not consent.

While the legal classification of failure to honour the stipulations accompanying a victim's consent to sexual intercourse appears, as mentioned above, fairly straightforward - especially given that stealthing may serve to spread infectious diseases, including HIV the provisions of Article 161 of the Criminal Code should not be overlooked. Following recent amendments, it now reads:

"Article 161, Paragraph 1. Whoever, knowing that they are infected with HIV, directly exposes another person to such an infection, shall be subject to the penalty of imprisonment for a term of between six months and eight years.

Paragraph 2. Whoever, knowing that they are infected with a sexually transmitted disease, an infectious disease, a serious, untreatable illness, or an illness that poses a real threat to life, directly exposes another person to such an illness, shall be subject to the penalty of imprisonment for a term of between three months and five years.

Paragraph 3. If the perpetrator of the act defined in Paragraph 2 exposes a large number of people to infection, they shall be subject to the penalty of imprisonment for a term of between one year and ten years. Paragraph 4. Prosecution of the offences defined in Paragraph 1 and Paragraph 2 above shall be instigated by the victim."

The above article, Article 161 of the Criminal Code, represents a kind of particularisation of the norm prohibiting the exposure of a person to the concrete risk of severe injury or death. The Article is distinguished by its description of the subjective aspect of the prohibited act (the awareness of a particular state of health that can endanger others if a perpetrator acts recklessly) and by the description of the result, to which the culpable act or conduct that occurs prior to the commission of the prohibited act is related analogous to the state of health of a perpetrator and different than described in Article 160 of the Criminal Code (Królikowski, Zawłocki, 2017). The rationale for specifying this prohibition is connected with society's sexual practices, which enable infectious diseases, as well as certain types of viruses that do not usually present a real threat to life, to be easily transmitted. Furthermore, as set out in the Criminal Code, it is possible to identify certain social or professional groups that are particularly vulnerable to harm from behaviour that presents a real threat of infection (Królikowski, Zawłocki, 2017). In the normative view, it can be stated that Article 161 of the Criminal Code is a regulation 'for our times'. It constitutes a criminal law response to new sources of risk to life and health arising from behaviour that exposes people to infection. While the threat from STDs has diminished, new types of infections and infectious diseases have appeared. They are the result of the globalisation of social life and especially of global migration. And their number continues to rise. In Article 161 of the Criminal Code the legislature placed emphasis on the threat to life and health arising from escalation of the risk of infection from HIV, which, as it significantly increases the risk of contracting infectious diseases, as well as other diseases, including cancer, is especially dangerous not only at the individual level but also at the group level (Stefański, 2020).

The crimes defined in Article 161 Paragraphs 1-3 of the Criminal Code protect human life and health. These legal goods make their appearance in two contexts: (1) as individualised goods vested in individuals, who are protected by the sanctioned norm included in this provision from the risk of infection and, as a result and indirectly, from the further consequences of infection and (2) as universal goods, which are intended under the terms of the provision to protect against the threat of epidemics by countering the spread of infections and diseases. This second line of protection is developed in Article 161 Paragraph 3 of the Criminal Code. The Criminal Code, which regulates the risk of infection in Article 161, does not specify the behaviour of a perpetrator in terms of actions or omissions. For their part, the possible means of infection are classified depending on whether exposure to infection concerns $\mathrm{HIV}$ or an infectious disease. The verbal phrase in this provision is therefore realised by any behaviour that results in the risk of infection (Królikowski, Zawłocki, 2017; Stefański, 2020).

It should be mentioned here that the typical transmission routes for infection include sexual intercourse, the external route, which includes cases of infection through tissue or organ transplants, transfusions of infected blood, artificial insemination, the use of needles, syringes and other skin-piercing objects, and, in perinatal situations, mother-to-child transmission. HIV infection occurs through human contact with any bodily fluid of an infected person. The virus is present in blood, saliva, semen, vaginal secretions, and breast milk. It is also present in the transudate fluid in an open wound. Contact with blood is particularly dangerous, as it contains the highest concentration of the infectious agent. In other human secretions or excretions, such as saliva or tears, the concentration is so low that the risk of infection is theoretical only (Królikowski, Zawłocki, 2017; Stefański, 2020). Understood in 
terms of the individual, the legal good protected by the type of prohibited act reconstructed in Article 160 Paragraph 1 or Paragraph 2 of the Criminal Code permits the proposition that, where a potential victim consents to take a risk (by, for example, having sexual intercourse in the knowledge that their partner is HIV positive) correspondence with the statutory features of the type of prohibited act under consideration here is not possible. This is known as Einverständnis consent, that is, consent as a circumstance that nullifies the essence of an act (Szczucki, 2011).

If we are to venture an analysis of the extent of the stealthing phenomenon, we cannot proceed without presenting at least basic data on the prevalence of the crime of rape and comparing them with overall crime statistics. Police statistics for confirmed instances of the crime of rape present a comparatively constant picture in the 1970-2008 period, which we shall examine by sub-period. In 1971-1973, incidences of rape per 100,000 inhabitants ranged from approximately 4.5 in 1971 to 9.8 in 1973 (Bocheński, 2016). The greatest decrease in cases of rape per 100,000 inhabitants occurred in 1973-1981, while in 1982-1984 there was a noticeable increase. By 1987, however, the proportion had almost returned to its 1981 level. Beginning in 1990, the magnitude of the offence of rape increased steadily until 1995 , when there were 2,267 recorded offences, which produces a ratio of 7.9 per 100,000 inhabitants. No distinct trend is identifiable for 1995 2000. By 2000, the ratio was comparable to those seen in the early 1970s. The fact that since 2000 there has been a fairly clear downward trend, and that in recent years the rate of the crime of rape has more or less stabilised, should be welcomed as grounds for cautious optimism. To progress the discussion, it is necessary to compare the number of confirmed offences of rape in Poland with an indicator of all recorded crimes. Doing so reveals that after 1990 the pattern of the incidence of rape per 100,000 inhabitants is not identical with the pattern of incidence of all recorded crimes. While in the light of the statistics recording confirmed crimes, crime grew noticeably and consistently in Poland in 1990-2003, the same cannot be said of the prevalence of the offence of rape (Marczewski, 2012), which has remained almost unchanged for a number of years.

It is necessary in the context of the above findings to attempt to identify the reasons for this state of affairs. To take the most obvious explanation that comes to mind when analysing the above data, we might conclude that the incidence of rape really has not changed compared to the incidence of crime overall. Yet in view of the fact that the incidence of the vast majority of offences, including those against life and health (especially assault, assault by beating, and actual bodily harm) and against property (especially theft), has increased, this judgment is open to question (Siemaszko, 2009). Given the noticeable increase in the incidence of the above crimes, it is difficult to accept that the offence of rape would not in any way follow the same pattern. This would also mean that alongside unchanged incidence - the reporting rates for the above crimes also remained at approximately the same level. Yet research into victimisation discloses that reporting rates were rising (Siemaszko, 2009). It is possible that the explanation for the differences in trends between the incidence of disclosed cases of rape and disclosed cases of crimes overall lies precisely in the question of rates of reporting.

It cannot be ruled out that the incidence of the offence of rape has in fact increased (as has that of all crime in Poland), but because the rate of reporting rape has declined, the statistics for confirmed crimes do not reflect this trend. It is of course necessary to acknowledge that rape, which concerns the intimate sphere of human sexual life, may indeed be less readily reported than other crimes. With reference to the crime defined in Article 197 of the Criminal Code it may not be without significance in this context that the offence of rape was prosecuted until 26 January 2014 at the instigation of the victim, which meant that a case could not be brought against their wishes. It is likely that victims' unwillingness to submit an application for prosecution had an impact on reporting rates for the acts in question. Their motives may have been fear of the perpetrator, reluctance to cause the prosecution and punishment of a loved one, and fear of the reaction of the law enforcement authorites, family, friends, and others in their immediate life environment. This is extremely difficult to evaluate without empirical research. Nevertheless, it is possible that because prosecution of the crime of rape was at the instigation of the victim, fewer offences were recorded in the statistics for confirmed offences than were actually committed, while the law enforcement authorities were able to record the crime of rape only as a result of a formal application for prosecution submitted by a victim. Furthermore, it was possible to obtain information about many other offences from sources other than a victim's notification and to conduct proceedings irrespective of the wishes of the victim.

It should be noted that in the period under discussion, 1970-2008, and especially after 1990, there were considerable changes in mores, such as increased freedom in sexual life (particularly in the cities). It is difficult to suppose that these changes have had no effect whatsoever on the incidence of the offence of rape. 
It would appear possible to venture the statement that a more 'liberated' way of life, as well as an easy-going approach to moral issues, mean that situations in which the crime of rape can occur arise often. Meanwhile victims, who are aware that they have actively co-created a criminogenic situation by their behaviour (Bieńkowska, 1984; Bochenski, 2010), do not report these incidents to the law enforcement authorities. It cannot be ruled out, though, that victims are indisposed to report their victimisation for fear of the reaction of the law enforcement authorities and out of an awareness of social attitudes that place the blame for rape on the victims themselves. This line of reasoning would lead, however, to the acknowledgement that preparedness to report offences of rape - unlike readiness to report other crimes - has fallen, which is not out of the question given the particularities of the offence.

The above discussion presents the picture of the offence of rape that emerges from the official crime statistics. There is no doubt that it would be enhanced by studies of victimisation, which constitute a valuable source of knowledge about actual crime. When their results and conclusions are considered alongside the official statistics, a more complete understanding of the magnitude of the crime is obtained. It is therefore appropriate to offer an account of the research into victimisation that deals with rape, and with child sexual abuse and exploitation. Beata Gruszczyńska's research into violence against women in Poland (2007), which is relevant to the crime defined in Article 197 of the Criminal Code, is among the best that has been done in this area. It examined the extent of sexual violence experienced by women by asking questions about the following: forced sexual intercourse (rape), attempted rape, touching a person's genitals and intimate areas against their will, forcing a person to have sex with other people, forcing a person to have sex for money, and other forms of sexual behaviour. Though these forms of sexual violence do not correspond directly with juridical categories in Polish law, the information from the research discussed above constitutes a valuable supplement to official crime statistics - especially in the area of rape and attempted rape. Gruszczyńska's research formed a part of the International Violence Against Women Survey (IVAWS). Interviews with 2,009 female repondents were conducted in the period from March to May 2004. The results indicated that $3.2 \%$ - or 64 - of the women studied had experienced rape (defined as forced sexual intercourse) during their lives, that $8.3 \%$ - or 168 - of those studied had fallen victim to attempted rape, and that $9.3 \%$ - or 187 of those studied had been touched in a sexual manner against their will. These three acts constituted the large majority of the sexual violence experienced by women (Gruszczyńska, 2007).

Given these results, the proposition may be ventured that the majority of the proportion of women in Poland who have experienced sexual violence during their lives $(16.5 \%)$ are highly likely to have been victims of acts which correspond with the statutory features of the type of prohibited act defined in Article 197 of the Criminal Code or with an attempt at such an act. Gruszczyńska's research also involved asking women about the sexual violence they had experienced in the five years preceding the surveys, and in the year immediately preceding them. If the results of these enquiries into victimisation were expressed in terms of the overall number of women in Poland in 2003, the conclusion would be that in this time almost 40,000 had fallen victim to rape, approximately 60,000 had been subjected to attempted rape, and more than 275,000 had been touched in a sexual manner aginst their will. Given that the number of offences confirmed at that time was many times lower (in 2003 there were 2,322 confirmed cases of rape), Gruszczyńska's research results provide further confirmation of the substantial size of the dark figure for the crime of rape.

The data presented above indicate that it is very problematical, if not impossible, to produce a reliable and accurate assessment of the extent of the crime of rape using criminal statistics alone. It is therefore advisable to make use of survey and self-report research into victimisation. And, given that the phenomenon is not recorded in any way in crime statistics, to employ methods of this kind is doubly justified in the case of stealthing. It should be pointed out here that if the behaviour under discussion in this paper is to be deemed rape (or, as another possibility, rape in conjunction with the prohibited act defined in Article 161 Paragraph 1 of the Criminal Code), it would, even if it were to appear in police data, definitely be recorded as part of the statistics for the offence of rape (as the principal act). Nevertheless, allowing the argument to complete its course, it may be noted that according to police statistics the incidence of the crime defined under Article 161 of the Criminal Code (not broken down by paragraphs) is similar to that of the crime defined in Article 197 of the Criminal Code: 683 offences were recorded in 1999, a peak of over 2,000 offences per year was reached in 2007-2010, and there was a return to relative stability with the current rate of approximately 1,600 offences per year. The incidence of stealthing is certainly not as great as that of rape. It would seem, however, that the seriousness of a situation should not 
be determined only by the scale of a particular social phenomenon, but also by its gravity, which is considerable where the behaviour concerned is so risky and has such far-reaching consequences. It is indicated by the lack of empirical studies and the absence of even theoretical sources that stealthing is an unresearched field that definitely warrants further investigation.

When assessed from the point of view of criminal law, the conduct under examination demonstrates that sexual crime, which is after all connected with the unparalleled power of the impulses of human sexuality, develops in a dynamic and unpredictable manner. The proposition that can be derived from this observation is that imposing barriers that amount only to penalising a particular behaviour as a type of prohibited act in the Criminal Code will not in fact be effective. Instead, the role to be played by criminal law is that of providing information on how, and to what extent, people can guard against such behaviour. Institutions tasked with preventing infection should pursue an appropriate information policy, while the judiciary should authorise prosecutions and conduct proceedings with a diligence commensurate with the seriousness of the act. Ultimately, this will curtail the actions of perpetrators of stealthing by clearly and firmly calling their behaviour a crime and uproot them, as it were, from the grey zone of embarassment, in which, relying on people's ignorance, unawareness and shame, they escape both public opprobrium and the proper criminal sanction. It is the hope of the authors that by addressing their arguments to both practitioners and theorists of the law, they will succeed in convincing them of the validity of the fears and concerns facing both individuals and the judiciary in the face of the new form of criminal sexual activity discussed here.

\section{References}

1. Arcimowicz, K. (2010). Obraz mężczyzny w polskich przekazach medialnych na przełomie stuleci. (In) M. Dąbrowska, A. Radomski (Eds.), Męskość jako kategoria kulturowa (pp. 10-25). Lublin: Portal Wiedza i Edukacja.

2. Bartnik, M. (2017). Odpowiedzialność karna za narażenie na zarażenie HIV i AIDS. Studia Prawnicze KUL, 7-15.

3. Bielski, M. (2006). Przestępstwa przeciwko wolności seksualnej i obyczajności. (In) A. Zoll (Ed.), Kodeks karny. Komentarz. Część szczególna (pp. 571-631). Kraków: Wolters Kluwer.

4. Bieńkowska, E. (1984). Wpływ zachowania ofiary na rozstrzygnięcie sprawy o zgwałcenie. Wrocław: Ossolineum.
5. Bocheński, M. (2010). Krytyczne spojrzenie na koncepcję przyczynienia się ofiary do zaistnienia przestępstwa zgwałcenia. Czasopismo Prawa Karnego i Nauk Penalnych, 14(3), 57-72.

6. Bocheński, M. (2016). Prawnokarna reakcja wobec sprawców przestęstw z art. 197 k.k. i art. 200 k.k. $w$ świetle teorii $i$ badań empirycznych. Warszawa: $\mathrm{CH}$ Beck.

7. Brodzikowska, M. (2013). Artykuł $161 \mathrm{KK}$ - zabezpieczenie czy niebezpieczeństwo? Retrieved July 13, 2021 from https:/www.researchgate.net/publication/ 307210479_Artykul_161_KK_-_zabezpieczenie_czy_ niebezpieczenstwo.

8. Budyn-Kulik, M. (2013). Zgwałcenie ze szczególnym okrucieństwem - art. 197 § 4 k.k. Warszawa: Instytut Wymiaru Sprawiedliwości. Retrieved July 13, 2021 from https://iws.gov.pl/wp-content/uploads/2018/08/kolor_ IWS_Budyn-Kulik-M_Zgwałcenia-ze-szczególnymokrucieństwem.pdf.

9. Burek, W., Gajewska, A. (2008). Odpowiedzialność karna za narażenie na zarażenie wirusem HIV drogą płciową. Ius Novum, 4, 42-56.

10. Cynkier, P. (2018). Czyny zabronione na tle zazdrości erotycznej u osób zdrowych psychicznie. Psychiatria Polska, 88, 1-14.

11. Dąbrowska, M., (2010). Męskość w okresie transformacji: zmiana ekonomiczno-społeczna a polityka płci na przykładzie debat aborcyjnych w Polsce. (In) M. Dąbrowska, A. Radomski (Eds.), Męskość jako kategoria kulturowa (pp. 25-41). Lublin: Portal Wiedza i Edukacja.

12. Dominiak, Ł. (2007). Problematyka seksualności w filozofii politycznej Michela Foucaulta. Metapolityka, 8, 277-295.

13. Ecler-Nocoń, B. (2016). Etyczne dylematy związane ze zmianą dotyczącą postrzegania ról płciowych podejmowanych przez kobiety i mężczyzn w rodzinie. Chowanna, 1, 101-116.

14. Filar, M. (1985). Przestępstwa przeciwko wolności seksualnej i obyczajności. (In) I. Andrejew (Ed.), System prawa karnego. Tom IV. Czesść 2., O przestęstwach w szczególności. Wrocław: Polska Akademia Nauk.

15. Filar, M. (1974). Przestepstwo zgwałcenia w polskim prawie karnym. Warszawa: Państwowe Wydawnictwo Naukowe.

16. Filar, M. (1986). Przestępstwo zgwałcenia. (In) I. Andrejew (Ed.), Kodeks karny. Krótki komentarz (p. 147). Warszawa: Państwowe Wydawnictwo Naukowe.

17. Gardocki, L. (2016). Prawo karne jako ultima ratio. Zasada i praktyka jej stosowania. (In) B. Namysłowska-Gabrysiak, K. Syroka-Marczewska, A. Walczak-Żochowska (Eds.), Prawo wobec problemów społecznych: księga jubileuszowa profesor Eleonory Zielińskiej (pp. 81-88). Warszawa: CH Beck. 
18. Głażewska, E. (2010). Owłosiony mężczyzna i bezwłosa kobieta, czyli dokąd zmierzamy? Genderowe znaczenie włosów. (In) M. Dąbrowska, A. Radomski (Eds.), Męskość jako kategoria kulturowa. Praktyki męskości (pp. 42-54). Lublin: Wydawnictwo Portalu Wiedza i Edukacja.

19. Górniok, O. (2005). Kodeks karny. Komentarz. Tom II. Art. 117-363. Gdańsk: Wolters Kluwer.

20. Grabowska, A. (1995). Procesy percepcji. Myślenie i rozwiąywanie problemów. Podejmowanie decyzji. Warszawa: Wydawnictwo Naukowe PWN.

21. Grabowska, M. (2014). Wychowanie seksualne a ryzykowne zachowania seksualne młodych dorosłych. Rocznik Lubuski, 40(1), 177-191.

22. Graupner, H. (2000). Sexual consent: The criminal law in Europe and overseas. Archives of Sexual Behavior, 29, 415-461.

23. Gruszczyńska, B. (2007). Przemoc wobec kobiet w Polsce. Aspekty prawnokryminologiczne. Warszawa: Wolters Kluwer.

24. Grygiel, A. (2010). Nowy model ojcostwa. (In) M. Dąbrowska, A. Radomski (Eds.), Męskość jako kategoria kulturowa. Praktyki męskości (pp. 55-67). Lublin: Wydawnictwo Portalu Wiedza i Edukacja.

25. Hryneńko, A. (2011). Wybrane metody regulacji poczęć stosowane u kobiet $i$ mężczyzn, praca licencjacka. Wydział Nauk o Zdrowiu, Uniwersytet Jagielloński.

26. Imacka, J., Bulsa, M. (2012). Ryzykowne zachowania seksualne młodzieży jako czynnik zwiększający ryzyko zakażenia chorobami przenoszonymi drogą płciową. $H y$ giea Public Health, 47(3), 272-276.

27. Izdebski, Z. (2003). Kwestie społeczne $i$ zachowania seksualne $w$ Polsce $w$ aspekcie problematyki HIV/AIDS. Studium porównawcze 1997-2001. Warszawa: Krajowe Centrum ds. AIDS.

28. Jabłońska, P. I., Naworska, B., Duda, A., Nieckula, M., Drosdzol-Cop, A. (2019). Analiza porównawcza metod antykoncepcyjnych stosowanych przez studentki $\mathrm{z}$ dwóch wybranych regionów Polski. Pielęgniarstwo i Zdrowie Publiczne, 9(4), 285-292.

29. Jakubowicz, J., Jakubowicz, O., Żaba, C., CzarneckaOperacz, M. (2009). Legal issues regarding HIV infection and AIDS disease. Postepy Dermatologii i Alergologii, 26(3), 150-154.

30. Karge, H., Pałka, P. (2018). Przestępstwo narażenia na zakażenie chorobą zakaźną (art. $161 \S 2$ k.k.) - przegląd problemów. Studia Prawnoustrojowe, 39, 65-81.

31. Klein, H. (2014). Generationing, stealthing, and gift giving: the intentional transmission of HIV by HIV-positive men to their HIV-negative sex partners. Health Psychology Research 22, 2(3), 54-59.

32. Knight, R. A., Prentky, R. A. (1990). Classifying sexual offenders: The development and corroboration of taxonomic models. (In) W. L. Marshall, D. R. Laws, H. E. Barbaree (Eds.), The handbook of sexual assault (pp. 23-52). New York: Springer.
33. Koronkiewicz, K. (2014). Kształtowanie tożsamości matki u kobiet doświadczających nieplanowanego macierzyństwa. Kultura Społeczeństwo Edukacja, 1(5), 95-118.

34. Królikowski, M., Zawłocki, R. (2017). Kodeks karny. Część szczególna. Komentarz do artykułów 117-221. Tom I. Warszawa: CH Beck.

35. Kusio, U. (2004). Współczesna kobieta wobec macierzyństwa. Kultura i Edukacja, 4, 40-47.

36. Kwiatkowska, G., Siudem, I. (Eds.), (2012). Zachowania ryzykowne. Lublin: Wydawnictwo UMCS.

37. Latimer, R. L., Vodstrcil, L. A., Fairley, C. K., Cornelisse, V. J., Chow, E. P., Read, T. R. H., Bradshaw, C. S. (2018). Non-consensual condom remowal, reported by patients at a sexual health clinic in Melbourne, Australia, PLOS One. Retrieved August 8, 2021 from https://doi. org/10.1371/journal.pone.0209779.

38. Lorber, J. (2010). Gender inequality feminist theories and politics. Oxford: Oxford University Press.

39. MacKinnon, C. A. (2006). Defining rape internationally: A comment on Akayesu. Columbia Journal of Transnational Law, 44(3), 940-958.

40. MacKinnon, C. A. (1991). Reflexions on sex equality under the law. The Yale Law Journal, 5, 1281-1328.

41. Mamak, K. (2017). Prawo karne przyszłości. Warszawa: Wolters Kluwer.

42. Mandal, E., Kocur, D. (2015). Poczucie władzy a poczucie satysfakcji seksualnej w intymnych relacjach. Seksuologia Polska, 13(1), 1-12.

43. Marczewski, M. (2012). Obraz statystyczny przestępstw z art. 197 k.k. (In) M. Mozgawa (Ed.), Przestepstwo zgwatcenia (pp. 197-213). Warszawa: Wolters Kluwer.

44. McCauley, H. (2016). Study gives doctors guidance on 'reproductive coercion'. Michigan: Michigan State University.

45. Mielnik, Z. (1997). Przestępstwa przeciwko życiu i zdrowiu w ujęciu nowego kodeksu karnego. Ruch Prawniczy Ekonomiczny i Socjologiczny, 59(4), 11-23.

46. Postanowienie Sądu Najwyższego z 9 kwietnia 2001 r., II KKN 349/98 (2001). Orzecznictwo Sądu Najwyższego. Izba Karna i Izba Wojskowa, 7-8, poz. 53.

47. Płatek, M. (2018). Zgwałcenie. Gdy termin nabiera nowej treści. Pozorny brak zmian i jego skutki. Archiwum Kryminologii, 40, 263-325.

48. Radomski, A. (2010). Kultura 2.0 a praktyki męskości. (In) M. Dąbrowska, A. Radomski (Eds.), Męskość jako kategoria kulturowa. Praktyki męskości (pp. 113-127). Lublin: Wydawnictwo Portalu Wiedza i Edukacja.

49. Rodzynkiewicz, M. (2006) Przestępstwa przeciwko wolności seksualnej i obyczajności. (In) A. Zoll (Ed.), Kodeks karny (pp. 598-631). Kraków: Zakamycze.

50. Schulhofer, S. J. (1995). The feminist challenge in criminal law. University of Pennsylvania Law Review, 143(6), 2151-2207. 
51. Schulhofer, S. J. (1998) Unwanted sex. The culture of intimidation and the failure of law (pp. 274-282). Cambridge: Harvard University Press.

52. Siemaszko, A. (Ed.), (2009). Atlas przestępczości w Polsce 4. Warszawa: Instytut Wymiaru Sprawiedliwości.

53. Stefański, R. A. (Ed.), (2020). Kodeks karny. Komentarz. Warszawa: Legalis.

54. Szczucki, K. (2011). Rola zgody w strukturze przestępstwa na przykładzie przestępstwa zgwałcenia. Czasopismo Prawa Karnego i Nauk Penalnych, 15(1), 31-58.

55. Szeląg, H., Wąż, K. (2015). Profilaktyka i poradnictwo dla dorosłych w zakresie HIV/AIDS. Zmieniające się potrzeby. Dyskursy Młodych Andragogów, 16, 115-127.

56. Warylewski, J. (2001). Przestępstwa przeciwko wolności seksualnej. Warszawa: CH Beck.

57. Warylewski, J. (2004). Przestępstwa przeciwko wolności seksualnej i obyczajności. (In) A. Wąsek (Ed.), Kodeks karny. Część szczególna. Komentarz. Tom I (pp. 7561005). Warszawa: CH Beck.

58. Warylewski, J. (2015). Szósta nowelizacja Kodeksu karnego w zakresie przestępstw seksualnych. Gdańskie Studia Prawnicze, 33, 403-413.

59. Wyrok Sądu Najwyższego z 10 października 2007 r., III KK 116/07, Legalis.

60. Wyrok Sądu Najwyższego z 13 lutego 1979 r., III KR 241/78, Legalis.

61. Wyrok Sądu Najwyższego z 18 lipca 1980 r., sygn. akt: III KR 149/80, Legalis.

62. Wyrok Sądu Najwyższego z 26 października 2001 r., WA 25/01 (2002). Orzecznictwo Sądu Najwyższego. Izba Karna i Izba Wojskowa, 1-2, poz. 6.

63. Wyrok Sądu Najwyższego z 26 września1974 r., III KR 105/7 (1974). Orzecznictwo Sądu Najwyższego. Izba Karna i Izba Wojskowa, 12, poz. 229.

64. Wyrok Sądu Najwyższego z 27 maja 1985 r., II KR 86/85 (1985). Orzecznictwo Sądu Najwyższego. Izba Karna i Izba Wojskowa, 12, poz. 152.

65. Zdrojewicz, Z., Lelakowska, K. (2006). Rola stresu w problemach, zaburzeniach i preferencjach seksualnych. Seksuologia Polska, 4(2), 69-79.

\section{Corresponding author}

Dr. Maciej Bocheński

Jagiellonian University

ul. Olszewskiego 2

PL 31-007 Kraków

e-mail: maciejk.bochenski@gmail.com 


\section{STEALTHING JAKO FORMA PRZESTECPSTWA ZGWALCENIA - DOTYCHCZASOWE USTALENIA I PRZYSZLE PERSPEKTYWY BADAWCZE}

W rozpoczętym trzecim dziesięcioleciu XXI wieku nauka o przestępstwie oraz dogmatyka prawa karnego ogniskuje się wokół rozpoznawania i opisywania nowych zachowań ludzkich jako czynów podlegających prawnokarnemu wartościowaniu głównie przy użyciu nowych technik masowego komunikowania się na odległość i służących do przesyłu danych (Mamak, 2017). Nie inaczej jest z przestępczością seksualną. Ostatnie lata przyniosły usankcjonowanie typów takich jak ujęte w art. 191a k.k., 202a k.k., 202b k.k., które wskazują, często nietrafiony, kierunek zainteresowania ustawodawcy w tym odcinku regulacji (Warylewski, 2015). Tymczasem „klasyczna” przestępczość seksualna pozostaje niemal niewzruszona $\mathrm{i}$ to - jak na przykładzie najbardziej oczywistym - art. 197 k.k. - od zarania współczesnej polskiej karnistyki (Budyn-Kulik, 2013). Nie sposób jednak w tak szybko zmieniającym się świecie oraz wraz $\mathrm{z}$ postępującą zmianą świadomości w zakresie praw reprodukcyjnych i szerzej - sfery wolności seksualnej - zignorować czy zbagatelizować pewne fragmenty ludzkiej aktywności „wymykające” się niejako dotychczasowym regułom i klasyfikacjom.

Zjawiskiem takim jest $\mathrm{z}$ pewnością stealthing lub inaczej non consensual condom removal (Latimer i in., 2018), czyli praktyka, w której partner w czasie stosunku (co istotne - nie tylko mężczyzna) usuwa lub uszkadza prezerwatywę bez wiedzy drugiego partnera/partnerki. Różne są elementy motywacyjne skłaniające do takiego zachowania i wstępnie sklasyfikować je można następująco:

- element władzy i dominacji nad partnerem (decydowanie o formie aktywności seksualnej);

- ryzykowne zachowania seksualne (możliwość niechcianej ciąży bądź zarażenia się chorobą weneryczną);

- motyw zemsty (przeważnie przez nosicieli chorób wenerycznych);

- prawo do nieskrępowanej reprodukcji (zasadniczo w stosunkach heteroseksualnych, gdzie mężczyźni manifestują w ten sposób swoje prawo do naturalnego ojcostwa i przekazywania swoich genów);

- element pragmatyczny (argumenty o słabszej jakości doznań $\mathrm{w}$ trakcie stosunku seksualnego $\mathrm{z}$ użyciem prezerwatywy);

- aspekt psychologiczny, np. chęć zatrzymania przy sobie partnerki/partnera i podejmowanie działań o znamionach stealthing $u \mathrm{w}$ nadziei, iż ich efektem będzie ciąża.
Mimo dość dużej rozbieżności między elementami wpływającymi na motywację sprawców samo zachowanie sprowadza się $\mathrm{w}$ istocie do jednego analogicznego zachowania - zdjęcia lub uszkodzenia prezerwatywy. Dla dalszych rozważań należy odróżnić sytuację, kiedy między stronami zostaje uzgodniony warunek podjęcia stosunku seksualnego bez korzystania z prezerwatywy, od takiej, w której w tym zakresie zachodzi jedynie pozorowana zgoda. Co do kwestii uszkadzania prezerwatyw, to zachowanie to zaczyna się nierzadko nie w warunkach pobudzenia seksualnego, w trakcie lub krótko przed podjęciem aktywności seksualnej, lecz odpowiednio wcześniej, co prezentują rozmaite, rozpowszechnione w sieci filmy instruktażowe pokazujące, jak prezerwatywę w sposób niezauważalny naciąc czy przedziurawić, by nie mogła pełnić swoich funkcji w zakresie antykoncepcji i prewencji wenerologicznej (McCauley, 2016). Wyłączyć w tym miejscu należy sytuacje, w których kobieta $\mathrm{w}$ nadziei zajścia $\mathrm{w}$ ciążę i posiadania potomstwa oświadcza niezgodnie z prawdą mężczyźnie przed współżyciem, że stosuje antykoncepcję hormonalną. Zjawisko to, jak się wydaje, dotyczy zgoła odmiennych przesłanek motywacyjnych i z tego względu pozostaje poza zakresem zjawiska stealthingu, a w konsekwencji także i niniejszego opracowania. Trzeba bowiem przypomnieć, że sama definicja stealthingu sprowadza to zachowanie do niepostrzeżonego usunięcia prezerwatywy. Jest rzeczą oczywistą, że nieporozumienia, oszustwa lub kłamstwa, do których dochodzi między partnerami seksualnymi $\mathrm{w}$ odniesieniu do stosowanych metod antykoncepcji, nie ograniczają się wyłącznie do potajemnego usunięcia prezerwatywy, natomiast w literaturze przyjmuje się, że pod pojęciem stealthingu rozumie się wyłącznie tę formę działań, opisaną na wstępie (McCauley, 2016; Latimer $\mathrm{i}$ in., 2018).

W celu przybliżenia omawianego zjawiska istotne i celowe wydają się rozwinięcie oraz szersza analiza pobudek i elementów motywacyjnych, jakie przyświecają sprawcom. Zgodnie z ideą ultima ratio normy prawnokarnej (Gardocki, 2016) nie tyle samo karanie winno być ostatecznością, ale już potrzeba stosowania kary jawi się jako pewien wyraz przegranej aparatu państwowego $\mathrm{i}$ - co za tym idzie - społeczeństwa w relacji do sprawcy i bezsilności w zakresie prewencji i probacji. Oczywiste jest, że i ,przeciwnik” jest niezwykle trudny, bo jest nim natura ludzka i swoista skłonność do zachowań niebezpiecznych, ryzykownych, nowych (Kwiatkowska, Siudem, 2012; Grabowska, 1995). Jak zawsze jednak kiedy 
w grę wchodzi stosowanie prawa karnego, należy dokonać wnikliwej oceny tego, gdzie kończy się obustronnie aprobowane zachowanie ryzykowne, a zaczyna nadużycie i krzywdzenie drugiej osoby.

Wydaje się, że kwestia zaspokajania potrzeby władzy i dominacji w zakresie relacji seksualnych między ludźmi nie budzi wątpliwości (Mandal, Kocur, 2015; Knight, Prentky, 1990; Dominiak, 2007). Równie powszechna (przynajmniej w kręgu kulturowym tzw. cywilizacji zachodniej) jest aprobata dla negatywnego wartościowania przemocy $\mathrm{w}$ stosunkach seksualnych, oczywiście o ile nie wyrażono na nią zgody (Graupner, 2000), choć aspekt momentu i formy wyrażenia zgody i przedmiotu tejże budzi pewne obiekcje (Płatek, 2018; Schulhofer, 1995, 1998; MacKinnon, 1991, 2006) i jest przedmiotem dyskusji. Obecnie we wspomnianym kręgu cywilizacyjnym partner podlega rygorowi odpowiedzialności prawnokarnej, o ile woli drugiej strony w zakresie wolności seksualnej nie uwzględnia (Graupner, 2000). Co oczywiste, wypracowane reguły budzą sprzeciw poszczególnych jednostek w odniesieniu do ich domniemanego prawa do decydowania o zakresie tego, co wolno lub nie. Szerzej o tej kwestii traktuje nauka o gender jako płci społecznej i jej odróżnieniu od płci biologicznej (Lorber, 2010). Podobnie kryminologia feministyczna dostarcza argumentów wskazujących na to, że społecznie funkcjonują określone przekonania, mity, stereotypy, które jedną ze stron (ściślej: mężczyznę) wskazują jako stronę uprzywilejowaną do władczego decydowania o zakresie i formie, a nawet samym zaistnieniu stosunku seksualnego (Płatek, 2018; Schulhofer, 1995, 1998; MacKinnon, 1991, 2006). W realiach omawianego zjawiska stealthin$g u$ sprawcy wprowadzają $\mathrm{w}$ błąd drugą stronę, pozorując wolę odbycia stosunku seksualnego z prezerwatywą, a potem, w jego trakcie, często w drodze impulsu seksualnego aktywującego pragnienie władzy i dominacji, usuwają zabezpieczenie. W tym modelu częstokroć fakt ten jest oświadczany drugiej stronie i nie podlega on w ocenie dokonującego żadnej dyskusji i nie stanowi jego zdaniem elementu istotnego $\mathrm{w}$ zakresie autonomii woli drugiej strony.

Zachowania $\mathrm{z}$ tzw. pogranicza lub ogół zachowań ryzykownych budzą napięcie seksualne i dla wielu osób w mniejszym lub większym stopniu mogą skłaniać do podjęcia lub niepodjęcia danej aktywności seksualnej (Grabowska, 2014). Wśród takich zachowań można wyróżnić dwa zasadnicze podtypy: ryzyko zajścia w ciążę oraz ryzyko (lub chęć) zarażenia się chorobą weneryczną (Imacka, Bulsa, 2012). Analizując dotychczasowe ustalenia nauki w tym zakresie, nie zauważa się szczególnie częstego występowania zjawiska zainteresowania kobiet zajściem w nieplanowaną ciążę (Kusio, 2004; Koronkiewicz, 2014). Jeśli w ogóle po stronie kobiet dochodzi do nadużycia (czy też wprowadzenia partnera w błąd), to częściej ich postępowanie sprowadza się do celowego doprowadzenia do zapłodnienia przez partnera, który nawet nie tyle usuwa prezerwatywę bez wiedzy lub zgody partnerki, co odbywa stosunek bez jej stosowania, a to z powodu fałszywego przeświadczenia o stosowaniu przez kobietę antykoncepcji hormonalnej. Natomiast drugi podtyp został zidentyfikowany i opisany wśród MSM (male have sex with male) - mężczyzn współżyjących z mężczyznami (Klein, 2014). Jego początki datować można na drugą połowę lat 80 . XX w., gdy po traumie, jaką była skala epidemii HIV, z jednej strony rozpoczęto stosowanie skutecznych terapii retrowirusowych oraz szeroko zakrojoną profilaktykę w postaci prezerwatyw wraz z powszechnie aprobowaną koncepcją tzw. safe sex, z drugiej jednak powstała grupa kontestatorów takich rozwiązań, którzy właśnie seks ryzykowny postrzegali jako atrakcyjny (Klein, 2014). Wtedy też po raz pierwszy zwrócono uwagę na zachowania polegające na wprowadzaniu w błąd, oszukiwaniu czy przymuszaniu do takiego współżycia tzw. safe bottoms, czyli mężczyzn chcących współżyć z założoną prezerwatywą (Klein, 2014). Wiek XXI przyniósł dalszy dynamiczny rozwój terapii retrowirusowej i jej znaczne uproszczenie (obecnie dziennie przyjmuje się niewielką ilość leku, najczęściej w jednej dawce), przełamanie społecznego tabu wokół HIV/AIDS oraz pojawienie się tzw. PrEP, czyli leków zapobiegających zarażeniu wirusem HIV oraz szeregiem innych chorób wenerycznych o podłożu wirusowym. Na drugim krańcu omawianego kontinuum pojawiły się natomiast coraz bardziej radykalizujące się postawy środowiska osób czerpiących największą przyjemność właśnie z ryzykownych zachowań seksualnych, w tym z możliwości zarażenia chorobą weneryczną lub HIV (Klein, 2014). W omawianej grupie wskazuje się między innymi na zjawisko generationing polegające na tym, że mężczyzna chory świadomie zaraża mężczyznę zdrowego, a potem oni wspólnie zarażają kolejnego mężczyznę. Zbliżonym zjawiskiem jest gift-giving, czyli sytuacja, w której seronegatywni meżczyźni aktywnie poszukujący możliwości bycia zarażonymi określani są jako bug-chaser, a seropozytywni, chcący zarazić kogoś, określani są jako gift-givers lub „poz” (od: positive - dodatni wynik testu na HIV; Klein, 2004). Nie powinno budzić żadnych wątpliwości, że rozpowszechnienie tego rodzaju praktyk i zachowań generuje znaczne ryzyko dla zdrowia publicznego, jako że zniweczyć może wieloletni wysiłek edukatorów seksualnych w zakresie profilaktyki wirusa HIV (Izdebski, 2003; Szeląg, Wąż, 2015).

Niestety przez wzgląd na charakter problemu określenie rozmiarów zjawiska, które można określić „HIV -entuzjazmem”, jest problematyczne. Zarówno badania ilościowe, jak i jakościowe napotykają ten sam problem w postaci niewystarczającej liczby potencjalnych respondentów (poszukiwanych na tematycznych forach lub grupach w portalach społecznościowych) chętnych do udzielenia odpowiedzi. Tym niemniej analiza 
zawartości niektórych mediów społecznościowych pozwala na stwierdzenie, że bynajmniej nie jest to zjawisko marginalne czy też możliwe do pominięcia. Na portalu Twitter można znaleźć szereg wpisów, które mogą unaocznić czytelnikowi postawy prezentowane przez osoby „HIV-entuzjastyczne”.

Swoista zemsta na przyszłych nieświadomych partnerach seksualnych za sytuacje $\mathrm{z}$ przeszłości, które doprowadziły do zarażenia danej osoby, również jest uważana za potencjalną motywację podejmowania stealthingu (Cynkier, 2018). Szersze rozważania co do akurat tej motywacji przeprowadzone będą pod kątem odpowiedzialności karnej z tytułu art. 161 k.k., gdyż ten typ do kodeksu karnego został wprowadzony w obliczu doniesień medialnych i dyskursu publicznego na temat sytuacji, w których mężczyzna z premedytacją zaraził kilkanaście/kilkadziesiąt kobiet wirusem HIV i brakowało instrumentu prawnego do właściwego zakwalifikowania takiego zachowania pod kątem prawnokarnym (Burek, Gajewska, 2008; Brodzikowska, Karge, Pałka, 2018; Mielnik, 1997; Jakubowicz, Jakubowicz, Żaba, Czarnecka-Operacz, 2009). Jeśli się rozważa sam mechanizm zemsty, to pełni on mechanizm redukcji, w jakim sfrustrowany i zły zarażony dzieli się swoim „złem” i w ten sposób - będąc samemu osobą, którą coś takiego spotkało - odczuwa satysfakcję, że nie tylko on zbiera negatywne skutki faktu bycia chorym i nie tylko on jest na tyle naiwny, nie dość inteligentny lub spotkał go wypadek losowy, że w trakcie swojej aktywności seksualnej uległ zarażeniu.

Przechodząc do kolejnego potencjalnego motywu i przyczyn zachowań omawianych w niniejszym artykule, warto wskazać na pewne modyfikacje w zakresie ról płciowych i ich znaczenia. Zmiana ról płciowych oraz stosunku społecznego do klasycznie pojmowanego macierzyństwa i ojcostwa spowodowały, że zdanie i wola kobiety co do czasu, w którym planowane jest potomstwo oraz jego liczby, stały się wiążące także dla drugiej, męskiej strony (Dąbrowska, 2010). Druga i trzecia fala feminizmu zmieniły również postrzeganie tego, czy kobieta musi w ogóle znaleźć partnera, z którym założy rodzinę (Grygiel, 2010), co spowodowało, mówiąc dość obrazowym językiem, „deficyt kobiet” oraz zwiększoną rywalizację między mężczyznami o partnerki w aspekcie seksualnym (Głażewska, 2010). Wraz z ukształtowaniem się swoistej odpowiedzi na feminizm w postaci tzw. inceli, czyli mężczyzn deklarujących się jako wprost nienawidzących kobiet, uaktywniły się postawy związane $\mathrm{z}$ postrzeganiem wyzwolenia się kobiet spod systemu patriarchalnego jako odebrania mężczyznom potencjalnej szansy na ojcostwo i przekazanie swoich genów (Radomski, 2010; Zdrojewicz, Lelakowska, 2006). Będąc jednak świadomymi panujących stosunków społecznych oraz w większości nie manifestując swoich poglądów $\mathrm{w}$ przestrzeni publicznej poza anonimowym zabieraniem głosu na forach i blogach internetowych, wspomniani mężczyźni podejmują jednorazowe, przypadkowe kontakty seksualne, w czasie których nie będąc narażonymi na finansowe i społeczne koszty ojcostwa, przekazują swoje geny nieświadomym niczego partnerkom, niejako „karząc je” za zmianę społeczną wywołaną przez feminizm i emancypację (Arcimowicz, Ecler-Nocoń, 2016).

Argument pragmatyczny jawi się jako najpowszechniej spotykany w sytuacji utrzymywania standardowych relacji seksualnych w stałych związkach hetero- $i$ homoseksualnych, w których partner wskazuje, że przez używanie prezerwatywy wyraźnie obniża się jego satysfakcja ze stosunku, gdyż prezerwatywa jest nieprzyjemna w kontakcie ze skórą członka, osoba jest uczulona na lateks, prezerwatywa jest niewłaściwego rozmiaru, uciska, uniemożliwia wzwód lub pełną ejakulację bądź powoduje nieprzyjemne wrażenia zapachowe i smakowe (Hryneńko, 2011; Jabłońska, Naworska, Duda, Nieckula, Drosdzol-Cop, 2019). Jeśli takie podejście do prezerwatywy jest aprobowane przez drugiego z partnerów, to rzecz jasna o stalthingu nie ma mowy, natomiast zaistnieje on w przypadku, gdy jeden z partnerów usuwa kondom bez wiedzy i zgody drugiej osoby.

Opisane w pierwszej części niniejszej publikacji zjawisko stealthing $u \mathrm{w}$ znacznej mierze jest, przynajmniej na pierwszy rzut oka, dość oczywiste do analizy z punktu widzenia jego prawnokarnej oceny. W sytuacji gdy mamy do czynienia z zachowaniem polegającym na tym, że w ramach aktywności seksualnej jedna osoba podejmuje działanie, którego druga osoba nie aprobuje (usunięcie prezerwatywy), nie można nie brać pod uwagę przestępstwa zgwałcenia jako właściwej kwalifikacji prawnej takiego zachowania. Dla porządku wypada zacząć od choćby pobieżnej jurydycznej analizy przestępstwa zgwałcenia na gruncie aktualnie obowiązującego w Polsce kodeksu karnego. Przestępstwo zgwałcenia jest typem czynu zabronionego określonym w art. 197 k.k. Treść wspomnianego przepisu jest następująca:

„Art. 197 § 1. Kto przemocą, groźbą bezprawną lub podstępem doprowadza inną osobę do obcowania płciowego, podlega karze pozbawienia wolności od lat 2 do 12 .

$\S 2$. Jeżeli sprawca, w sposób określony w $\S 1$, doprowadza inną osobę do poddania się innej czynności seksualnej albo wykonania takiej czynności, podlega karze pozbawienia wolności od 6 miesięcy do lat 8 .

$\S 3$. Jeżeli sprawca dopuszcza się zgwałcenia:

1) wspólnie $z$ inną osobą,

2) wobec małoletniego poniżej lat 15 ,

3) wobec wstępnego, zstępnego, przysposobionego, przysposabiającego, brata lub siostry, podlega karze pozbawienia wolności na czas nie krótszy od lat 3 .

$\S 4$. Jeżeli sprawca czynu określonego w $\S 1-3$ działa ze szczególnym okrucieństwem, podlega karze pozbawienia wolności na czas nie krótszy od lat 5". 
Jako że gruntowna analiza typu czynu zabronionego z art. 197 k.k. przekracza ramy niniejszego tekstu, zasadne będzie skupienie się przede wszystkim na tych spośród kwestii dogmatycznych, które są relewantne z punktu widzenia problematyki stealthingu.

Jak wskazuje się w piśmiennictwie, indywidualny przedmiot ochrony w art. 197 k.k. stanowi wolność seksualna rozumiana jako wolność ,od” wszelkich nacisków w przedmiocie podejmowania decyzji w zakresie stosunków seksualnych, a więc wolność od przymusu w sferze zachowań seksualnych (Rodzynkiewicz, 2006; Andrejew, 1986). Ochrona wolności seksualnej w art. 197 k.k. zgodnie z ugruntowanym stanowiskiem Sądu Najwyższego obejmuje prawo do decydowania o miejscu, czasie, sposobie i innych warunkach podejmowanej aktywności seksualnej (Postanowienie Sąu Najwyższego, 2001). Zgwałcenie jest niezwykle jaskrawym przejawem naruszenia tak rozumianej wolności seksualnej, bowiem w wypadku zastosowania wobec ofiary środków oddziaływania wymienionych w art. 197 k.k. nie dochodzi najczęściej w ogóle do podjęcia przez nią swobodnej decyzji woli w przedmiocie jej życia seksualnego (Bielski, 2006; Filar, 1985). Zaznaczyć trzeba, że w orzecznictwie Sądu Najwyższego wielokrotnie podkreślano, iż na gruncie obecnie obowiązującego kodeksu nie jest relewantne to, w jakim celu sprawca działał, istotne jest natomiast to, czy swoim zachowaniem - odpowiadającym ustawowemu opisowi - dopuścił się zamachu na wolność seksualną ofiary (Postanowienie Sądu Najwyższego, 2001; Wyrok Sądu Najwyższego, 2007). Warto w tym kontekście zwrócić uwagę, że w sytuacji, w której sprawca nie godził w dobro prawne w postaci wolności seksualnej, wykluczona będzie odpowiedzialność karna z art. 197 k.k., nawet jeśli jego zachowanie polegało na ingerencji w sferę integralności cielesnej w obrębie sfer intymnych innej osoby - np. oddychanie usta-usta czy wykonanie lewatywy (Bielski, 2006). Godzi się wskazać także na wyrok Sądu Najwyższego z 26 października 2001 r., w którym stwierdzono, iż usunięcie owłosienia łonowego jako forma ,grubiańskiego żartu” nie stanowiło realizacji znamion art. 197 § 3 w zw. § 2 k.k., chociaż łączyło się z kontaktem sprawców z narządami płciowymi ofiary, gdyż nie było to zachowanie zmierzające do naruszenia wolności w sferze życia seksualnego, a co najwyżej stanowiło naruszenie nietykalności cielesnej ofiary (Wyrok Sądu Najwyższego, 2001). Warto zatem podkreślić, że w obecnym kształcie uregulowania znamion typu czynu opisanego w art. 197 k.k. odpowiedzialność karna sprawcy za przestępstwo zgwałcenia jest uzależniona od dopuszczenia się zamachu na wolność seksualną osoby pokrzywdzonej, nie zaś od szczególnego nastawienia psychicznego sprawcy do swojego czynu przejawiającego się w działaniu w celu zaspokojenia popędu seksualnego. Do przestępnego naruszenia wolności seksualnej może zatem dojść z motywów pozaseksualnych (Bielski, 2006).

W zakresie przywołania znamion przestępstwa zgwałcenia należy wskazać, iż w doktrynie prawa karnego wyróżnia się niewypowiedziane znamię tego typu czynu zabronionego, jakim jest brak zgody pokrzywdzonego. Jest ono konstatacją tyleż istotną, co oczywistą, że przyzwolenie (wyrażenie zgody) na obcowanie płciowe lub inną czynność seksualną wyklucza kryminalną bezprawność zachowania opisanego w art. 197 k.k. (Warylewski, 2004; Górniok, 2005; Bielski, 2006). Warto podkreślić, że brak zgody musi istnieć w chwili czynu (Wyrok Sądu Najwyższego, 1980, 1979) i co do zasady powinien być w jakiś sposób zwerbalizowany lub chociaż uzewnętrzniony (Warylewski, 2004).

Elementami stanowiącymi znamiona przestępstwa z art. 197 k.k. są również przemoc, groźba bezprawna i podstęp. Rozważając podstęp jako znamię przestępstwa zgwałcenia, warto zacząć od wyrażonego jeszcze na gruncie poprzednio obowiązującego kodeksu karnego stanowiska Sądu Najwyższego, którego zdaniem istota podstępu w rozumieniu przepisów o zgwałceniu sprowadza się do podjęcia przez sprawcę takich zabiegów o oszukańczym charakterze, które zdolne są nawet rozważną kobietę doprowadzić do poddania się czynowi nierządnemu (Wyrok Sądu Najwyższego, 1974). W przywołanym orzeczeniu Sąd Najwyższy wyraźnie zwrócił uwagę na kryterium indywidualno-obiektywne przy dokonywaniu oceny, czy zachowanie sprawcy realizowało znamię stosowania podstępu. Podobnie w orzeczeniu z 27 maja 1985 r. wskazał on, iż ,podstęp, o którym mowa w art. 168, może polegać bądź na stosowaniu takich pozorów, w których osoba pokrzywdzona wyraża zgodę na czyn nierządny, na który nie wyraziłaby zgody, gdyby nie była wprowadzona w błą, bądź też na zabiegach doprowadzających osobę pokrzywdzoną do stanu, w którym nie ma pełnego rozeznania tego, co czyni, albo nie może stawiać oporu. W każdym razie podstęp w rozumieniu art. 168 k.k. wyłącza lub w znacznym stopniu ogranicza wolę osoby pokrzywdzonej przeciwstawienia się zamierzonemu doprowadzeniu jej w ten sposób przez sprawcę do poddania się czynowi nierządnemu" (Wyrok Sądu Najwyższego, 1985).

W doktrynie, podobnie jak w orzecznictwie, uznanie zyskało szerokie ujęcie podstępu na gruncie przestępstwa zgwałcenia, wedle którego podstępem jest zarówno wywołanie lub wykorzystanie błędu ofiary odnośnie do istotnych przesłanek motywacyjnych stanowiących podstawę powzięcia decyzji co do zaangażowania seksualnego - tzw. ujęcie wąskie, jak również poprzedzone wprowadzeniem w błąd lub wykorzystaniem błędu ofiary doprowadzenie jej do takiego stanu, w którym wykluczona jest swobodna autodeterminacja seksualna, a to z uwagi na wyłączenie aparatu decyzyjnego albo ruchowego - tzw. ujęcie szerokie (Filar, 1974). 
W literaturze wskazuje się, że zachowania podstępne to także takie, które co prawda prowadzą do podjęcia przez ofiarę samodzielnej decyzji w przedmiocie nawiązania kontaktu seksualnego, ale ta decyzja nie może zostać uznana za prawnie relewantną zgodę na czynność seksualną z uwagi na działanie ofiary pod wpływem błędu (Bielski, 2006; Filar, 1974). Istotnym z punktu widzenia realizacji znamion art. 197 k.k. błędem co do motywów decyzji o zadysponowaniu wolnością seksualną jest taki błąd, którego skutkiem jest sytuacja, w której dysponent dobra nie ma świadomości wszystkich okoliczności faktycznych istotnych dla jej podjęcia. Zawierać się tu będzie m.in. wykorzystanie błędu ofiary co do osoby partnera stosunku seksualnego albo wprowadzenie w błąd przez osobę niebędącą lekarzem co do tego, że dotykanie sfer intymnych jest częścią badania lekarskiego (Bielski, 2006).

W kontekście zjawiska opisanego w niniejszej publikacji nie powinno budzić wątpliwości, że stealthing, a zatem usunięcie prezerwatywy bez wiedzy i zgody partnera seksualnego, stanowić będzie realizację znamion przestępstwa zgwałcenia przy pomocy podstępu. Gdy jeden z partnerów godzi się na współżycie seksualne z drugą osobą z zastrzeżeniem, że do stosunku seksualnego dojdzie $z$ użyciem prezerwatywy, to usunięcie jej bez wiedzy i zgody osoby, która od jej użycia uzależniała stosunek seksualny, stanowi niewątpliwe doprowadzenie podstępem do obcowania płciowego w warunkach, na które nie było zgody pokrzywdzonego.

$\mathrm{O}$ ile przełamanie woli pokrzywdzonego w zakresie warunków współżycia seksualnego, na jakie się on godzi, i kwalifikacja prawna takiego zachowania jawi się, jak to wyżej wspomniano, jako dość oczywista, to szczególnie w kontekście informacji o tym, że zjawisko stealthingu może służyć rozpowszechnianiu chorób zakaźnych, w tym wirusa HIV, nie można tracić z pola widzenia zakresu normowania art. 161 k.k. Przepis ten po ostatnio dokonanych nowelizacjach ma obecnie brzmienie:

„Art. 161. § 1. Kto, wiedząc, że jest zarażony wirusem HIV, naraża bezpośrednio inną osobę na takie zarażenie, podlega karze pozbawienia wolności od 6 miesięcy do lat 8 .

$\S 2$. Kto, wiedząc, że jest dotknięty chorobą weneryczną lub zakaźną, ciężką chorobą nieuleczalną lub realnie zagrażającą życiu, naraża bezpośrednio inną osobę na zarażenie taką chorobą, podlega karze pozbawienia wolności od 3 miesięcy do lat 5 .

$\S 3$. Jeżeli sprawca czynu określonego w $§ 2$ naraża na zarażenie wiele osób, podlega karze pozbawienia wolności od roku do lat 10 .

$\S 4$. Ściganie przestępstwa określonego w $§ 1$ i 2 następuje na wniosek pokrzywdzonego."

Komentowany przepis jest swego rodzaju uszczegółowieniem normy mówiącej o zakazie narażenia człowieka na konkretne niebezpieczeństwo ciężkiego uszczerbku na zdrowiu lub pozbawienia życia. Wyróżnia go opis strony podmiotowej czynu (świadomość określonego stanu zdrowia, który jest źródłem niebezpieczeństwa w przypadku nieostrożnego zachowania sprawcy), opis skutku, do którego odnoszona jest kryminalizacja na przedpolu jego wystąpienia - analogiczny do stanu zdrowia sprawcy oraz inny niż opisany w art. 160 k.k. (Królikowski, Zawłocki, 2017). Sens wyodrębnienia takiego zakazu wynika z praktyk życia seksualnego w społeczeństwie, które umożliwiają łatwe przenoszenie się chorób zakaźnych oraz transmisję pewnego rodzaju wirusów, w przypadku których zarażenie nie musi powodować choroby realnie zagrażającej życiu. Jednocześnie można wskazać pewne grupy społeczne lub zawodowe, które są szczególnie narażone na uszczerbek wynikający $\mathrm{z}$ opisanych $\mathrm{w}$ ustawie zachowań sprowadzających realne niebezpieczeństwo zarażenia (Królikowski, Zawłocki, 2017). Normatywne ujęcie art. 161 k.k. pozwala na stwierdzenie, że jest to regulacja „na miarę naszych czasów". Przepis ten stanowi reakcję prawa karnego na nowe źródła niebezpieczeństwa dla zdrowia lub życia, wynikające z zachowań narażających na zakażenia. Zmniejszyła się groźba chorób wenerycznych, pojawiły się jednak nowe rodzaje zakażeń i chorób zakaźnych, których liczba, choćby w związku z globalizacją życia społecznego, w tym zwłaszcza globalną migracją, nieustannie rośnie (Stefański, 2020). W art. 161 k.k. ustawodawca zaakcentował zagrożenie dla życia i zdrowia wynikające z eskalacji ryzyka zakażenia wirusem HIV, szczególnie niebezpiecznego nie tylko w aspekcie jednostkowym, ale także grupowym. Zwiększa ono bowiem znacząco ryzyko zachorowań na choroby zakaźne, ale także na inne choroby, w tym nowotworowe (Stefański, 2020).

Przedmiotem ochrony przestępstw określonych w art. $161 \S 1-3$ k.k. jest życie i zdrowie człowieka. Dobra te występują w podwójnym kontekście: $\mathrm{z}$ jednej strony jako dobra zindywidualizowane, przynależne jednostce, którą norma sankcjonowana zawarta $\mathrm{w}$ tym przepisie chroni przed niebezpieczeństwem zakażenia, a w konsekwencji pośrednio także przed następstwami, jakie stan taki za sobą pociąga; z drugiej zaś - jako dobra powszechne, którym należy zapewnić bezpieczeństwo wobec zagrożenia epidemicznego przez zapobieganie rozprzestrzenianiu się zakażeń i chorób zakaźnych określonych w dyspozycji tego przepisu. Ten drugi kierunek ochrony znajduje rozwinięcie w szczególności w dodanym przepisie art. $161 \S 3$ k.k.

W zakresie znamion czynnościowych ustawa bliżej nie określa sposobu zachowania sprawcy. Możliwe sposoby zakażeń, jakich ryzyko reguluje art. 161 k.k., są zróżnicowane w zależności od tego, czy narażenie na zakażenie dotyczy wirusa HIV czy też choroby zakaźnej. Znamię czasownikowe przewidziane w tym przepisie realizuje więc każde zachowanie, z którego wynika niebezpieczeństwo zakażenia (Królikowski, Zawłocki 2017; 
Stefański, 2020). Należy w tym miejscu wspomnieć, że do typowych dróg przenoszenia zarażenia (zakażenia) należy współżycie płciowe, droga zewnętrzna, obejmująca przypadki zakażenia przez przeszczepy tkanek lub narządów, transfuzje zakażonej krwi, sztuczne zapłodnienie oraz używanie igieł, strzykawek, a także innych przedmiotów przebijających skórę oraz, w sytuacjach okołoporodowych, w przypadku przenoszenia zarażenia z matki na dziecko. Do zakażenia HIV dochodzi w wyniku kontaktu człowieka z każdym płynem ustrojowym osoby zakażonej. Wirus ten jest obecny we krwi, ślinie, nasieniu, wydzielinie pochwowej, także mleku matki. Występuje też w płynie przesiękowym w otwartej ranie. Szczególnie niebezpieczny jest kontakt z krwią, bowiem w niej jest największe stężenie czynnika zakaźnego. $\mathrm{W}$ innych wydzielinach lub wydalinach człowieka (np. ślina, łzy) jest na tyle niewielkie, że ryzyko zakażenia jest możliwe jedynie teoretycznie (Królikowski, Zawłocki, 2017; Stefański, 2020).

Indywidualistycznie pojmowane dobro chronione typem rekonstruowanym z art. $160 \S 1$ lub 2 k.k. pozwala na stwierdzenie, że w przypadku zgody potencjalnego pokrzywdzonego na podjęcie ryzyka (np. współżycie seksualne przy wiedzy o tym, że partner jest nosicielem wirusa HIV) znosi możliwość wypełnienia znamion typu czynu zabronionego - tzw. konstrukcja Einverständnis, czyli zgoda jako okoliczność znosząca istotę czynu; (Szczucki, 2011).

Aby pokusić się o analizę dotyczącą rozmiarów zjawiska stealthingu, nie sposób nie przedstawić choćby podstawowych danych dotyczących rozmiarów przestępczości zgwałcenia w świetle danych ze statystyk kryminalnych.

Statystyka policyjna wskazuje względnie stałą dynamikę stwierdzonych przestępstw zgwałcenia w latach 1970-2018. Współczynnik nasilenia przestępczości zgwałcenia w przeliczeniu na 100 tys. mieszkańców waha się w omawianym okresie w przedziale od ok 4,5 w 1971 r. do 9,8 w 1973 r. (Bocheński, 2016). Właśnie w okresie od 1973 do 1981 r. zaobserwować można największy spadek rozmiarów omawianej przestępczości, natomiast w latach 1982-1984 nastąpił ich zauważalny wzrost, aby w roku 1987 niemal powrócić do stanu z 1981 r. Począwszy od 1990 roku rozmiary przestępczości zgwałcenia systematycznie rosły aż do roku 1995, osiągając poziom 2267 przestępstw stwierdzonych, co daje współczynnik 7,9 na 100 tys. mieszkańców. Lata 1995-2000 to okres, w którym nie zaznaczyła się żadna wyraźna tendencja. W roku 2000 rozmiary przestępczości zgwałcenia osiągnęły rozmiary porównywalne z tymi $\mathrm{z}$ początku lat 70 . $Z$ pewnym optymizmem należy przyjąć fakt, iż od tego czasu, tj. od 2000 roku, dość wyraźnie zaznacza się tendencja zniżkowa, zaś w ostatnich latach rozmiary przestępczości zgwałcenia są $\mathrm{w}$ gruncie rzeczy ustabilizowane (Bocheński, 2016).
Omawiając liczbę stwierdzonych przestępstw zgwałcenia w Polsce, należałoby także przyjrzeć się rozmiarom tej przestępczości na tle ogólnego wskaźnika dynamiki przestępczości. Analizując tę kwestię, zauważyć należy, iż dynamika współczynnika nasilenia zgwałceń nie pokrywa się z dynamiką ogólnego współczynnika przestępczości po roku 1990. O ile, w świetle statystyki przestępstw stwierdzonych, rozmiary przestępczości w Polsce rosły zauważalnie i systematycznie w okresie 1990-2003, to nie można tego samego powiedzieć o rozmiarach przestępczości zgwałcenia (Marczewski, 2012), które pozostają właściwie na niezmienionym od lat poziomie.

W kontekście powyższych ustaleń należy podjąć próbę odpowiedzi na pytanie o przyczyny takiego stanu rzeczy. Stosunkowo najbardziej oczywistym wyjaśnieniem nasuwającym się przy analizie powyższych danych jest stwierdzenie, iż rozmiary przestępczości zgwałcenia w przeciwieństwie do rozmiarów przestępczości w ogóle są rzeczywiście niezmienne. Taki wniosek może jednak budzić wątpliwości ze względu na fakt, iż rozmiary zdecydowanej większości przestępstw, w tym m.in. przestępstw przeciwko życiu i zdrowiu (szczególnie udział w bójce lub pobiciu, spowodowanie uszczerbku na zdrowiu) oraz przeciwko mieniu (przede wszystkim kradzież) wzrosły (Siemaszko, 2009). Trudno jest zatem przypuszczać, iż przy zauważalnym wzroście współczynników wspomnianych przestępstw przestępstwa zgwałcenia w najmniejszym stopniu nie podzieliłyby tego trendu. Oznaczałoby to również, że przy niezmienionych rozmiarach także zgłaszalność omawianych przestępstw pozostała na zbliżonym poziomie. $Z$ badań wiktymizacyjnych odnoszących się do tego zagadnienia wynika jednak, że wskaźniki zgłoszeń rosną (Siemaszko, 2009).

Być może właśnie w kwestii zgłaszalności należy doszukiwać się przyczyn różnic $\mathrm{w}$ tendencjach między rozmiarami ujawnionej przestępczości zgwałcenia a rozmiarami przestępczości ujawnionej w ogóle. Nie można wykluczyć, iż rozmiary przestępczości zgwałcenia faktycznie wzrosły (podobnie jak rozmiary całej przestępczości w Polsce), jednak ze względu na spadek zgłaszalności tych przestępstw statystyka przestępstw stwierdzonych tej tendencji nie odzwierciedla. Oczywiście trzeba zaznaczyć, że zgwałcenie jako dotyczące intymnej sfery życia seksualnego człowieka rzeczywiście może być mniej chętnie zgłaszane niż inne przestępstwa. W przypadku przestępstwa $\mathrm{z}$ art. 197 k.k. nie bez znaczenia w tym kontekście może być fakt, iż do 26 stycznia 2014 r. przestępstwo zgwałcenia było ścigane na wniosek, co oznacza, że niemożliwe było prowadzenie postępowania wbrew woli osoby pokrzywdzonej. Jest prawdopodobne, że na zgłaszalność omawianych czynów miała wpływ niechęć do składania przez ofiarę wniosku o ściganie. Motywem takiego zachowania ofiar mógł być strach przed sprawcą, 
niechęć do spowodowania ścigania i ukarania bliskiej osoby, a także obawa przed reakcją organów ścigania i najbliższego otoczenia. Jest to niezwykle trudne do oceny i wymagałoby przeprowadzenia badań empirycznych w tym zakresie, natomiast być może właśnie ze względu na wnioskowy tryb ścigania przestępstwa zgwałcenia do statystyki przestępstw stwierdzonych trafiało ich mniej niż rzeczywiście popełniono, natomiast organy ścigania (w przeciwieństwie do wielu innych przestępstw, w przypadku których możliwe było uzyskanie informacji o popełnionym przestępstwie także z innych źródeł niż zawiadomienie osoby pokrzywdzonej i prowadzenie postępowania niezależnie od jej woli) mogły zarejestrować takie przestępstwo wyłącznie na skutek złożenia przez osobę pokrzywdzoną formalnego wniosku o ściganie.

Należy zauważyć, że w omawianym okresie, tj. w latach 1970-2008, szczególnie zaś po 1990 roku, doszło do znaczących zmian w kwestiach obyczajowych, nastąpiło m.in. zwiększenie swobody życia seksualnego (szczególnie w miastach). Trudno przypuszczać, iż zmiany te nie wpłynęły w żaden sposób na rozmiary przestępczości zgwałcenia. Wydaje się, że można zaryzykować stwierdzenie, że bardziej „wyzwolony” styl bycia, jak również swobodne podejście do kwestii obyczajowych sprawiają, iż często dochodzi do sytuacji, w których ma miejsce przestępstwo zgwałcenia, natomiast osoba pokrzywdzona, mając świadomość, że swoim zachowaniem aktywnie współkształtowała sytuację kryminogenną (Bieńkowska, 1984; Bocheński, 2010), nie zgłasza tego faktu organom ścigania. Z drugiej strony nie można wykluczyć, że właśnie w obawie przed taką reakcją - zarówno społeczeństwa, jak i przede wszystkim organów ścigania, wobec świadomości postaw społecznych, w myśl których ofiary zgwałceń są „same sobie winne” - osoby pokrzywdzone niechętnie zgłaszają fakt wiktymizacji. Takie rozumowanie prowadziłoby jednak do przyznania, iż gotowość do zgłaszania przestępstw zgwałcenia w przeciwieństwie do gotowości zgłaszania innych przestępstw spadła, co nie jest wykluczone, jeśli się weźmie pod uwagę specyfikę omawianego przestępstwa.

Powyżej przedstawiono obraz przestępczości zgwałcenia wyłaniający się z oficjalnych statystyk kryminalnych. Dane te $\mathrm{z}$ całą pewnością warto uzupełnić o informacje płynące $\mathrm{z}$ badań wiktymizacyjnych, które stanowią ważne źródło wiedzy na temat rzeczywistej przestępczości. Wyniki takich badań i płynące z nich wnioski wspólnie z oficjalnymi statystykami składają się na pełniejszy obraz dotyczący rozmiarów przestępczości. Dlatego też celowe wydaje się przedstawienie badań wiktymizacyjnych dotyczących zgwałcenia oraz wykorzystywania seksualnego małoletnich.

W zakresie dotyczącym przestępstwa z art. 197 k.k. do bodaj najbardziej wartościowych badań należy zaliczyć badania Gruszczyńskiej dotyczące przemocy wobec kobiet w Polsce (Gruszczyńska, 2007). Nasilenie przemocy seksualnej doświadczanej przez kobiety było tam badane za pomocą pytań dotyczących następujących zdarzeń: zmuszenia do stosunku seksualnego (zgwałcenie), usiłowania zgwałcenia, dotykania miejsc intymnych wbrew woli, zmuszania do zachowań seksualnych z udziałem innych osób lub zmuszania do seksu za pieniądze oraz innych form zachowań seksualnych. Jakkolwiek zdarzenia te nie są tożsame $\mathrm{z}$ kategoriami jurydycznymi, to jednak - szczególnie w zakresie zgwałcenia i usiłowania zgwałcenia - dane z omawianych badań stanowią cenne uzupełnienie danych $\mathrm{z}$ oficjalnych statystyk kryminalnych.

Wspomniane badania stanowiły część Międzynarodowych Badań nad Przemocą wobec Kobiet (IVAWS). Wywiady z 2009 respondentkami zostały przeprowadzone w okresie od marca do maja 2004 r. Rezultaty badań wskazują, że 3,2\% badanych kobiet (64 osoby) w ciągu całego swojego życia doświadczyło zgwałcenia - definiowanego jako wymuszony stosunek seksualny. Ofiarą usiłowania zgwałcenia padło 8,3\% badanych (168 osób), zaś seksualnego dotykania wbrew woli $9,3 \%$ badanych (187 osób). Wymienione czyny stanowiły zdecydowaną większość doświadczanej przez kobiety przemocy seksualnej (Gruszczyńska, 2007). Można więc, w świetle wyników cytowanych badań, zaryzykować stwierdzenie, iż z ogólnej liczby 16,5\% kobiet w Polsce doświadczających przemocy seksualnej w czasie swojego życia większość pada ofiarą czynów, które z dużym prawdopodobieństwem realizują znamiona typu czynu zabronionego określonego w art. 197 k.k. lub usiłowania takiego czynu.

W badaniach pytano także o doświadczoną przez kobiety przemoc seksualną $\mathrm{w}$ ciągu ostatnich 5 lat przed badaniem i w ciągu ostatniego roku poprzedzającego badanie. Próba przełożenia wyników powyższych badań wiktymizacyjnych na ogólną liczbę kobiet w Polsce w 2003 roku prowadziłaby do konkluzji, iż w tym czasie blisko 40 tys. kobiet padło ofiarą zgwałcenia, blisko 60 tys. usiłowania zgwałcenia, natomiast ponad 275 tys. padło ofiarą seksualnego dotykania wbrew woli. W kontekście faktu, iż liczba przestępstw stwierdzonych w tym czasie była wielokrotnie mniejsza (w 2003 roku były to 2322 stwierdzone przestępstwa zgwałcenia), wyniki badań Gruszczyńskiej stanowią kolejne potwierdzenie znacznych rozmiarów ciemnej liczby w odniesieniu do przestępstwa zgwałcenia.

Przedstawione powyżej dane wskazują, że dokonanie rzetelnej i trafnej oceny rozmiarów zjawiska przestępczości zgwałcenia za pomocą samych tylko statystyk kryminalnych jest wysoce utrudnione, a nawet niemożliwe. $\mathrm{Z}$ tego względu zasadne okazuje się posiłkowanie się badaniami ankietowymi w postaci badań wiktymizacyjnych lub self-report. Sięgnięcie po taką metodę analizy jest $\mathrm{w}$ dwójnasób usprawiedliwione $\mathrm{w}$ przypadku stealthingu, jako że w statystykach kryminalnych takie zachowania nie są w żaden sposób wyodrębniane. 
Należy również w tym miejscu wskazać, że jeśli omawiane $\mathrm{w}$ niniejszej publikacji zachowanie oceniać jako zgwałcenie (ewentualnie zgwałcenie w zbiegu z czynem $\mathrm{z}$ art. $161 \S 1$ k.k.), to nawet jeżeli takie czyny zawierały się $\mathrm{w}$ danych policyjnych, to $\mathrm{z}$ pewnością $\mathrm{w}$ ramach statystyki przestępstwa zgwałcenia (jako czynu głównego). Tym niemniej dla porządku można wskazać, że rozmiary przestępczości z art. 161 k.k. (bez „rozbicia” na paragrafy) według statystyki policyjnej są zbliżone do rozmiarów przestępczości z art. 197 k.k. (od 683 przestępstw stwierdzonych w 1999 r. przez szczyt w latach 2007-2010, kiedy stwierdzano ponad 2000 przypadków rocznie, do względnej stabilizacji, obecnie na poziomie ok. 1600 przestępstw stwierdzonych rocznie).

Rozmiary zjawiska stealthingu nie są z pewnością tak znaczne, jak skala całej przestępczości zgwałcenia. Wydaje się jednak, że o powadze sytuacji nie powinny decydować wyłącznie względy wolumenu określonego zjawiska społecznego, ale także jego ciężar gatunkowy, a ten jawi się w przypadku tak ryzykownych i brzemiennych w skutki zachowań jako znaczny. Brak badań empirycznych, a nawet brak źródeł choćby teoretycznych wskazuje, że stealthing pozostaje obszarem niezbadanym, który z pewnością wymaga dalszych badań.

Analizowane zachowanie, oceniane $\mathrm{z}$ punktu widzenia prawnokarnego wartościowania, wskazuje na to, w jak zdynamizowany oraz nieprzewidywalny sposób rozwija się przestępczość seksualna, powiązana przecież z najsilniejszymi bodźcami odnoszącymi się do seksualności człowieka. Twierdzenie, które można wyprowadzić z tej uwagi, stanowi, że w istocie nakładanie barier sprowadzających się wyłącznie do spenalizowania określonego zachowania jako typu w ustawie karnej nie będzie efektywne. Rolą, której należy tu upatrywać dla prawa karnego, jest funkcja informująca o tym, w jakim zakresie ludzie mogą się przed takim zachowaniem ustrzec. Instytucje zajmujące się profilaktyką zakażeń powinny prowadzić odpowiednią politykę informacyjną, natomiast organa wymiaru sprawiedliwości - usankcjonować ściganie oraz prowadzenie postępowań z należytą starannością co do powagi czynu, a więc ostatecznie zminimalizować zachowania sprawcze osób podejmujących stealthing poprzez klarowne i stanowcze nazwanie ich zachowań przestępstwem, wyciągając ich niejako z szarej, wstydliwej strefy, w której, bazując na ludzkiej niewiedzy, nieświadomości i wstydzie, uciekają od odpowiedzialności zarówno związanej bezpośrednio z odium społecznym, jak i z należytą sankcją karną. W nadziei autorów publikacji pozostaje, by docierając zarówno do praktyków, jak i teoretyków prawa, wzbudzić przekonanie o zasadności obaw i trosk stojących przed jednostką, ale też przed wymiarem sprawiedliwości w obliczu omówionej nowej formy przestępczej aktywności seksualnej. 